\title{
Determination of paleoseasonality of fossil brachiopods using shell spiral deviations and chemical proxies
}

Joanna V. Clark ${ }^{a}{ }^{*}$, Alberto Pérez-Huerta $^{a}{ }^{*}$, David P. Gillikin ${ }^{b}$, Anthony E. Aldridge ${ }^{c}$, Matias Reolid ${ }^{\mathrm{d}}$, Kazuyoshi Endo ${ }^{\mathrm{e}}$

${ }^{a}$ Department of Geological Sciences, University of Alabama, Tuscaloosa, Alabama, 35487, USA

${ }^{\mathrm{b}}$ Department of Geology, Union College, Schenectady, New York, 12308, USA

${ }^{c}$ PO Box 19576, Woolston, Christchurch, 8241, New Zealand

${ }^{\mathrm{d}}$ Departamento de Geología, Universidad de Jaen, Campus Las Lagunillas s/n, 23071

Jaén, Spain

${ }^{\mathrm{e}}$ Department of Earth and Planetary Sciences, The University of Tokyo, Tokyo 113-003, Japan

* Corresponding authors. E-mail addresses: jvclark@crimson.ua.edu; aphuerta@ua.edu Current address of Clark: Apt. 3202, 1800 South Egret Bay Blvd., League City, TX, USA

\begin{abstract}
Brachiopods have been extensively used in paleoclimatic and paleoecological reconstructions, but their utility would greatly increase if paleoseasonality information could be obtained from their shells. Determining seasonal seawater temperature variations from fossil brachiopods requires knowledge of specimen ontogenetic ages, which is difficult to determine compared to other organisms secreting a shell by accretion. In this study, the combination of the spiral deviation methodology and chemical proxies is tested for determining specimen ontogenetic ages and paleoseasonality using two species of fossil brachiopods, Laqueus rubellus and
\end{abstract} Terebratula terebratula, of Pleistocene and Late Miocene age, respectively. Spiral deviations were obtained for Laqueus and Terebratula using an R program developed for modern taxa, and well-preserved shells were analyzed using oxygen isotopes and $\mathrm{Mg} / \mathrm{Ca}$ ratios as chemical proxies for past seawater temperature. Results reveal that locations of 
spiral deviations on shells of $L$. rubellus displayed a strong direct relationship with $\mathrm{Mg}$ concentrations, and resulting $\mathrm{Mg} / \mathrm{Ca}$-derived paleotemperatures were seasonal. Conversely, specimens of $T$. terebratula did not show a consistently strong relationship between Mg concentrations and spiral deviations, although resulting paleotemperatures agreed with those from previous studies. Overall, the results from this study indicate that the spiral deviation methodology combined with chemical proxies presents great potential for utility in past seasonal seawater temperature reconstructions in pristinely preserved, biconvex fossil brachiopods.

Keywords: $\mathrm{Mg} / \mathrm{Ca} ; \delta^{18} \mathrm{O}$; morphometrics; seawater temperature; paleoecology

\section{Introduction}

Brachiopods are excellent recorders of paleoecological and paleoclimatic information because they have a long geologic history, represent one location and water depth, are geographically widespread, have modern representatives, and have lived in a variety of marine habitats throughout the Phanerozoic (e.g., Brand et al., 2011, 2012; Ivany, 2012; Pérez-Huerta et al., 2014; Garbelli et al., in press). Brachiopods have been particularly useful in reconstructing past climatic conditions, in particular seawater temperature and ocean chemistry, because they precipitate calcite shells in oxygen isotopic equilibrium with ambient seawater, and these shells are very resistant to diagenesis (e.g., Carpenter and Lohmann, 1995; Geldern et al., 2006; Suan et al., 2008; Yamamoto et al., 2010; Brand et al., 2013). Additionally, $\mathrm{Mg} / \mathrm{Ca}$ ratios have demonstrated great potential as a past seawater temperature proxy in the adult portions of modern brachiopod shells (Lee et al., 2004; Pérez-Huerta et al., 2008, 2014; Butler et al., 2015). Thus, brachiopods have been used extensively to reconstruct past seawater temperature changes at low resolution in temporal scales of thousands to millions of years over the geologic record (e.g., Veizer et al., 1986; Suan et al., 2008; Giles, 2012; Mii et al., 2012). Currently, fossil brachiopods are not considered ideal bioarchives for obtaining past seasonal seawater temperature variability because this determination requires knowledge of specimen ontogenetic ages, which are difficult to estimate in comparison to other organisms secreting carbonate shells (e.g., bivalve mollusks; Klein et 
al., 1996; Dettman et al., 1999; Surge et al., 2001; Ivany et al., 2004; Surge and Lohmann, 2008; among others). Thus, an accurate methodology that improves ontogenetic age determination would greatly expand the utility of brachiopods in paleoclimate research.

In modern taxa, ontogenetic ages and growth rates have been analyzed based on in situ shell measurements and population studies of living brachiopods, although these studies are sparse (e.g., Thayer, 1977; Curry, 1982). Growth rates have also been studied using approaches combining shell chemistry and growth lines (Barbin and Gaspard, 1995; Yamamoto et al., 2010), but both of these methods have associated problems that limit their effectiveness in fossils (see Pérez-Huerta et al., 2014 and references therein). Additionally, Roark et al. (2016) and Powell et al. (2009) attempted to investigate seasonality by analyzing the growth lines and shell chemistry of fossil brachiopods, but none of these studies analyzed shell morphometry. More recently, shell spiral deviations (SSD) have been used to determine ontogenetic ages of modern brachiopods, where deviations of the shell outline from a perfect logarithmic spiral represent changes in growth (Aldridge and Gaspard, 2011; Pérez-Huerta et al., 2014; Clark et al., 2015). The combination of SSD, other morphological approaches to shell growth, and chemical proxies for seawater temperature have been shown to be potentially more effective in determining ontogenetic ages as well as seasonality in modern brachiopod species (PérezHuerta et al., 2014; Butler et al., 2015). Approaches that combine shell chemistry and morphometry to investigate seasonality, however, have not yet been tested on fossil specimens. In this study, two fossil brachiopod species are analyzed by combining their

spiral deviations (SSD) and chemical proxies for temperature $\left(\delta^{18} \mathrm{O}\right.$ and $\mathrm{Mg} / \mathrm{Ca}$ ratios $)$ to determine whether shell spiral deviations are potentially useful in specimen ontogenetic age determinations and past seasonal seawater temperature reconstructions.

\section{Materials and methodology}

\subsection{Sample information}

The brachiopods analyzed in this work include specimens of the species Laqueus rubellus (Family Laqueidae) and Terebratula terebratula (Family Terebratulidae) (Fig. 
1). These specimens were used to develop the R code for obtaining specimen ontogenetic ages of fossil brachiopod shells in Clark et al. (2015). Thus, sample collecting sites and geological context for both species is provided in Clark et al. (2015) and reiterated here to facilitate the understanding of the present contribution. Additionally, a description of ideal brachiopod specimens for spiral deviation analysis is included in Clark et al. (2015). Shell parameters (length, width, and thickness) and spiral deviations (Table 1) are determined for three complete specimens of each species, with larger specimens selectively chosen to maximize the shell growth record (see Pérez-Huerta et al., 2014; Clark et al., 2015). Both species possess biconvex shells without ornamentations, such as spines.

\section{Fig. 1.}

\section{Table 1.}

\subsubsection{Laqueus rubellus (Sowerby, 1846)}

Shells of Laqueus were collected from the Jizodo Formation (0.39 Ma) and the Yabu Formation (0.31 Ma) of the Shimosa Group in central Japan. The depositional environment of specimen collection is representative of a shallow embayment, known as the paleo-Tokyo Bay. More specifically, the Jizodo Formation contains facies associated to littoral and sub-littoral zones (Endo, 1987). Fossil specimens of this species were selected as a "control group" because equivalent modern individuals can be collected from the Sagami Bay at water depths between 70-90 m, and have been use to determine shell spiral deviations and seasonality (Pérez-Huerta et al., 2014).

\subsubsection{Terebratula terebratula (Linnaeus, 1758)}

Specimens were collected from the Tortonian (Upper Miocene) deposits of the Guadix Basin, a Neogene intra-mountain basin located in southern Spain, connected with the Atlantic Ocean through the Guadalquivir Basin. They correspond to accumulations in prodelta facies with an inferred depth around $30 \mathrm{~m}$ (see more details in Reolid et al., 2012). 


\subsection{Sample preparation}

Samples had to be cleaned first to ensure that there was minimal unconsolidated material adhered onto the outside of the shells. Shells were then embedded in epoxy resin and cut with a Buehler Isomet 1000 Precision Saw along the plane of symmetry, producing two identical halves. The shell surface of each half was ground and polished with aluminum oxide $(1.0$ and $0.3 \mu \mathrm{m})$ until the surface was flat and free of scratches. These polished shell surfaces were used for determining shell spiral deviations and geochemical analyses. For more detail on sample preparation techniques, see Clark et al. (2015).

\subsection{Spiral deviations}

Both valves of each specimen were digitized using the image-digitization software, Vextrator 3.6.1 (available at http://www.vextrasoft.com/download.htm). Resulting $(\mathrm{x}, \mathrm{y})$ coordinates were imported into the computer program $\mathrm{R}$ (Gentleman and Ihaka, 1997), and previously developed R code was used to create spiral deviation graphs using the methodology discussed in detail in Clark et al. (2015) (Fig. 2).

\section{Fig. 2.}

\subsection{Scanning electron microscopy (SEM)}

One specimen within each species was analyzed to image its shell microstructure using a JEOL-7000 SEM instrument at the University of Alabama Central Analytical Facility (CAF) to assess preservation. Samples of the shell anterior region were etched with $2 \%$ hydrochloric acid for 20 seconds and coated with gold for 90 seconds using a sputter coater. Imaging was acquired at $30 \mathrm{keV}$, a current of $15 \mathrm{ohms}$, and a working distance of approximately $10 \mathrm{~mm}$. Specimens were imaged at the anterior-most and posterior-most regions of each valve at various magnifications.

\subsection{Electron backscatter diffraction (EBSD)}


Highly-polished surfaces of the anterior-most region of a resin-embedded shell, which included both the dorsal and ventral valves, was cut to an approximate size of $(1 \times$ $2 \times 0.5) \mathrm{cm}$ in order to fit on the EBSD holder inside of the aforementioned SEM instrument. Samples were coated with a $2.5 \mathrm{~nm}$ thick coating of carbon using a Gatan model 681 high-resolution ion beam coater. The following SEM settings were used for EBSD analysis: voltage of $30 \mathrm{keV}$, current of $15 \mathrm{ohms}$, and a working distance of approximately $10 \mathrm{~mm}$. The following EBSD settings were used during analysis: binning of $4 \times 4$, low gain, frame averaging of 1 , and step size of approximately 1 . Calcite was chosen as an identifying phase in all specimens. EBSD maps were created for dorsal and ventral valves of every specimen using AZtec 2.0 software, and then analyzed with EDAX OIM 5.3 processing software. EBSD data is represented by diffraction and crystallographic maps and pole figures are in reference to the $\{0001\}$ plane of calcite (see Pérez-Huerta et al., 2014).

\subsection{Magnesium analysis and $\mathrm{Mg} / \mathrm{Ca}$ thermometry}

In preparation for trace element analysis, sample cross-sections were marked with locations of spiral deviations. In order to do this, a biological outline with locations of deviations marked as red points was created using the $\mathrm{R}$ package (see Section 2.3.). This graph was overlain on a high resolution image of the shell cross section on Adobe Illustrator, and this image was used as a reference when marking locations of spiral deviations on the shell cross section. Locations of spiral deviations were marked with a fine tipped needle on the resin immediately adjacent to the shell in cross sections. These marks were numbered on the resin in order to indicate which deviation it was and whether it was positive or negative (e.g., positive deviation closest to the umbo).

Samples were analyzed for $\mathrm{Mg}$ concentrations, using the isotope ${ }^{25} \mathrm{Mg}$, on a laser ablation — inductively coupled plasma — mass spectrometer (LA-ICP-MS) at Union College in Schenectady, NY. In this analysis, a CETAC LSX-213 frequency quintupled Nd:YAG laser $(\lambda=213 \mathrm{~nm})$ coupled to a Perkin Elmer Elan 6100 DRC ICP-MS was used according to methods stated in Gillikin and Dehairs (2013).

Daily performance tests were run every day prior to analysis using NIST 612 as a reference to ensure that $\mathrm{ThO} / \mathrm{Th}$ values were less than $1 \%$ and Indium counts were above 
25000 counts/second. These values from the standard indicated that the instrument was running optimally and would produce reliable results. Standards were run at the start of each day and in between samples to allow for recalibration of samples as well as observation of daily instrumental drift. National Institute of Standards and Technology (NIST) 612 and NIST 610 were used as standard reference material and the United States Geological Survey MACS-3 pressed carbonate standard (values from the USGS) was used as a reference sample. Brachiopod samples were analyzed using point analysis, a spot size of $50 \mu \mathrm{m}$, a laser energy of $100 \%$, shot frequency of $10 \mathrm{~Hz}$, shutter delay of 20 seconds, and a burst count of 600 . Helium was used as the carrier gas $(600 \mathrm{~mL} / \mathrm{min})$, which was mixed with argon after the ablation cell $(840 \mathrm{~mL} / \mathrm{min})$.

Brachiopod specimens were analyzed at locations of deviations within the anterior regions, which had been marked prior to analysis (Fig. 3). Trace element sampling was done at locations in the innermost part of the shell within the secondary layer, which contains stable Mg concentrations representative of original seawater chemistry (PérezHuerta et al., 2008; Fig. 3). Additionally, one specimen within each species was analyzed at locations of spiral deviations in both the anterior and posterior regions. Each deviation location was analyzed at three spots, which were separated by approximately $50 \mu \mathrm{m}$ (Fig. $3)$.

\section{Fig. 3.}

After analysis, elemental concentrations were calculated using GeoPro (CETAC) software. In this software, samples were corrected using the 20 -second gas blank prior to each sample analysis when the shutter was closed. Samples were calibrated with NIST 612 and NIST 610 (values from Pearce et al., 1997), using ${ }^{43} \mathrm{Ca}$ as the internal standard. Elemental measurements were converted from signals in counts/second to concentrations in ppm. A detection limit was calculated for $\mathrm{Mg}$ by multiplying the standard deviation of NIST-612 blanks by 3. All analyses were well above the $13.79 \mathrm{ppm} \mathrm{Mg}$ detection limit. Standard deviations were calculated using MACS-3 elemental concentrations that were run over the course of the analyses; the mean relative standard deviation (\%RSD) for ${ }^{25} \mathrm{Mg}$ was $4.32 \%$. 
The corrected $\mathrm{Mg}$ values as well as average $\mathrm{Ca}$ concentrations, which had been determined for each species using a Perkin Elmer Optima 3000 Dual View inductively coupled plasma-optical emission spectrometer (ICP-OES) at the University of Alabama $(\mathrm{Ca}=375000 \mathrm{ppm}$ for L. rubellus and $\mathrm{Ca}=368000 \mathrm{ppm}$ for T. terebratula $)$, were used to calculate past seawater temperatures using the equation from Pérez-Huerta et al. (2008, 2014). Additionally, two $\mathrm{Mg} / \mathrm{Ca}$ paleothermometry equations developed by Butler et al. (2015), based on the modern brachiopods Terebratulina retusa and Liothyrella neozelanica, were used as a comparison. The three temperatures at each deviation location were averaged and standard deviations were calculated. These temperatures were compared to temperatures from previous studies as well as the resulting oxygen isotope paleotemperatures.

\subsection{Oxygen isotope analysis and $\delta^{18} O$ thermometry}

Samples were drilled with a New Wave micromill at the inner secondary layers of the shells, only at locations thick enough for sampling (Fig. 3). The inner secondary layer is precipitated in oxygen isotopic equilibrium with ambient seawater (Parkinson et al., 2005), and is therefore the most ideal sampling location. Sampling was done within the anterior regions of the shells, but the positions were not precisely homologous among samples. The purpose of this analysis was to determine if the $\mathrm{Mg} / \mathrm{Ca}$ paleotemperatures were within the same range as the oxygen isotope paleotemperatures. By doing so, we hope to demonstrate the reliability of the calculated $\mathrm{Mg} / \mathrm{Ca}$ paleotemperatures. The shell powder was placed on weighing paper and weighed on a Sartorius milligram scale until there was 50-100 $\mu \mathrm{g}$ of powder. The sample powder was then placed into $4 \mathrm{~mL}$ roundbottom glass vials, which were sealed to proper tightness. Five samples were taken from each valve of each fossil brachiopod specimen.

Fourteen vials in each analysis were allotted for the standard NBS-19, which was powdered using a mortar and pestle and measured into 50-100 $\mu \mathrm{g}$ aliquots. The sample vials were placed in a Thermo Gas Bench II, which maintained a temperature of $50^{\circ} \mathrm{C}$. Each sample vial was flushed with helium gas for 10 minutes. Each sample was then acidified with $100 \%$ orthophosphoric acid using a syringe in order to liberate $\mathrm{CO}_{2}$ from the samples. The acidified samples were then analyzed in a Thermo Delta Plus 
continuous flow - isotope ratio mass spectrometer (CF-IRMS) at the University of Alabama Stable Isotope Laboratory for $\delta^{18} \mathrm{O}$, using NBS-19 as a standard. Precision was better than $0.09 \%$ for oxygen.

Temperatures were calculated using resulting $\delta^{18} \mathrm{O}$ values from the shells based on the equation of Epstein et al. (1953) modified by Anderson and Arthur (1983), which has also been used in previous studies on brachiopods by Curry and Fallick (2002) and Parkinson et al. (2005), with $\delta^{18} \mathrm{O}_{\mathrm{w}}$ in reference to VSMOW.

$\mathrm{t}_{\left({ }^{\circ} \mathrm{C}\right)}=16.0-4.14\left(\delta^{18} \mathrm{O}_{\mathrm{c}}-\delta^{18} \mathrm{O}_{\mathrm{w}}\right)+0.13\left(\delta^{18} \mathrm{O}_{\mathrm{c}}-\delta^{18} \mathrm{O}_{\mathrm{w}}\right)^{2}$,

where $\delta^{18} \mathrm{O}_{\mathrm{c}}$ represents shell $\delta^{18} \mathrm{O}$ values and $\delta^{18} \mathrm{O}_{\mathrm{w}}$ represents water $\delta^{18} \mathrm{O}$ values. In this study, $\delta^{18} \mathrm{O}_{\mathrm{w}}$ was assumed to be 0 (\%o VSMOW) based on values used in previous studies involving samples from similar time periods (Williams et al., 2005; Findlater et al., 2014). The paleothermometry equation of Brand et al. (2013) was not used so that resulting temperatures were solely a reflection of oxygen isotopic composition, not magnesium composition.

\section{Results}

\subsection{Spiral deviations}

Spiral deviations generated from specimens of L. rubellus and T. terebratula were wide and large in magnitude (Figs. S1 and S2). Shells of L. rubellus produced between three and four spiral maxima and minima per valve (Fig. S1) and between three and six spiral maxima and minima per valve for shells of T. terebratula (Fig. S2).

\subsection{Shell preservation}

In order to validate that the shell chemical data reflects primary signals, shells of both species were analyzed for preservation using SEM and EBSD analyses. SEM images of L. rubellus confirm that these shells are in pristine condition in terms of microstructure (Fig. 4). Well-preserved primary and secondary layers are recognized, with the latter consisting of both transversally and longitudinally cut fibers perforated by 
hollow punctae for both valves. EBSD analysis of the dorsal and ventral valves of $L$. rubellus specimens confirms exceptionally well-preserved shell material (Fig. 5).

Secondary layer fibers contain calcite crystals with $c$-axes oriented perpendicular to the outer shell surface as in modern species (Cusack et al., 2008; Schmahl et al., 2012), and there is no evidence of recrystallization or secondary mineral phases.

\section{Fig. 4.}

\section{Fig. 5.}

SEM analysis of $T$. terebratula reveals the absence of a primary layer but the presence of a well-preserved fibrous secondary layer consisting of mostly transversally cut fibers (Fig. 6). Punctae are present across the whole shell thickness but seem to be filled with secondary calcite. EBSD analysis confirms the presence of a relatively wellpreserved secondary layer, as observed in L. rubellus, and with punctae completely filled with small crystals of secondary calcite with multiple crystallographic orientations (Fig. 7).

\section{Fig. 6.}

\section{Fig. 7.}

\subsection{Geochemical proxies and seawater temperature}

\subsection{1. $\delta^{18} \mathrm{O}$ values}

Average $\delta^{18} \mathrm{O}$ values in specimens of L. rubellus ranged between 0.7 and $1.3 \%$ (VPDB), and values from the dorsal and ventral valves were within range of each other (Table 2). Resulting average paleotemperature estimates from both dorsal and ventral valves ranged between $10.5^{\circ} \mathrm{C}$ and $12.9^{\circ} \mathrm{C}$ (Table 2).

Average $\delta^{18} \mathrm{O}$ values in specimens of T. terebratula ranged between -0.8 and $0.1 \%$ (VPDB), and values from the dorsal and ventral valves were within range of each 
other. Calculated temperatures ranged between $15.7^{\circ} \mathrm{C}$ and $19.7^{\circ} \mathrm{C}$ (Table 2).

\section{Table 2.}

\subsection{2. $\mathrm{Mg} / \mathrm{Ca}$}

Average $\mathrm{Mg} / \mathrm{Ca}$ values in specimens of L. rubellus ranged between 5.17 and 8.61 $\mathrm{mmol} / \mathrm{mol}$, and values from the dorsal and ventral valves were within range of each other (Table 3). Resulting temperatures ranged between $8.07^{\circ} \mathrm{C}$ and $12.86^{\circ} \mathrm{C}$ using the $\mathrm{Mg} / \mathrm{Ca}$ thermometry equation by Pérez-Huerta et al. (2008), between $14.39^{\circ} \mathrm{C}$ and $19.80^{\circ} \mathrm{C}$ using the equation by Butler et al. (2015) based on the modern brachiopod T. retusa, and between $6.02^{\circ} \mathrm{C}$ and $9.02^{\circ} \mathrm{C}$ using the equation by Butler et al. (2015) based on the modern brachiopod L. neozelanica (Table 3).

Average $\mathrm{Mg} / \mathrm{Ca}$ values in specimens of $T$. terebratula ranged between 8.43 and $10.74 \mathrm{mmol} / \mathrm{mol}$, and values from the dorsal and ventral valves were within range of each other (Table 3). For temperature calculations, we used the same approach as for $L$. rubellus, and resulting temperatures ranged between $11.58^{\circ} \mathrm{C}$ and $16.15^{\circ} \mathrm{C}, 19.52^{\circ} \mathrm{C}$ and $21.89^{\circ} \mathrm{C}$, and $8.89^{\circ} \mathrm{C}$ and $10.46^{\circ} \mathrm{C}$ (Table 3).

\section{Table 3.}

\subsection{3. $\mathrm{Mg} / \mathrm{Ca}$ ratios and spiral deviations}

$\mathrm{Mg} / \mathrm{Ca}$ ratios were compared to the locations of spiral deviations in L. rubellus and T. terebratula using the approach described in Pérez-Huerta et al. (2014) (Figs. 8 and 9; Figs. S1 and S2). High $\mathrm{Mg} / \mathrm{Ca}$ ratios were recorded at major spiral maxima and low $\mathrm{Mg} / \mathrm{Ca}$ ratios were recorded at major spiral minima in the following deviation points of valves of L. rubellus: 1 dorsal, 2 dorsal, 2 ventral, 3 dorsal, 4 dorsal, 4 ventral, and 5 ventral (Table 4; Fig. 8; Fig. S1). Although the ventral valve of specimen 1 displayed a relationship between deviations and $\mathrm{Mg} / \mathrm{Ca}$ ratios in the posterior region of the shell, it was not observed as strongly in the anterior region. Using the equation by Pérez-Huerta et al. (2008), the average temperature variation between major maxima and minima in 
specimens of $L$. rubellus was $6.40^{\circ} \mathrm{C}$ in 1 dorsal, $7.48^{\circ} \mathrm{C}$ in 1 ventral, $9.74^{\circ} \mathrm{C}$ in 2 dorsal, $9.20^{\circ} \mathrm{C}$ in 2 ventral, $3.47^{\circ} \mathrm{C}$ in 3 dorsal, $6.30^{\circ} \mathrm{C}$ in 4 dorsal, $6.79^{\circ} \mathrm{C}$ in 4 ventral, and $7.62^{\circ} \mathrm{C}$ in 5 ventral. These variations were similar between valves of the same shell, although the variations were not consistent between shells. The temperature variations between major spiral maxima and minima ranged between $6.30^{\circ} \mathrm{C}$ and $9.74^{\circ} \mathrm{C}$, except for 3 dorsal which had a lower variation of $3.47^{\circ} \mathrm{C}$. Spiral deviations that were interpreted to be the same in both valves did not consistently record the same temperature value, although this could be due to a slight offset in sampling locations (Table 4).

\section{Table 4.}

Fig. 8.

\section{Fig. 9.}

There was not a consistently strong relationship between $\mathrm{Mg} / \mathrm{Ca}$ ratios and major spiral deviations in specimens of T. terebratula (Table 5; Fig. 9; Fig. S2). However, high $\mathrm{Mg} / \mathrm{Ca}$ ratios were recorded at major spiral maxima and low $\mathrm{Mg} / \mathrm{Ca}$ ratios were recorded at major spiral minima in the dorsal valve of specimen 1 and the ventral valve of specimen 3 (Table 5; Fig. 9; Fig. S2). Using the equation by Pérez-Huerta et al. (2008), the average temperature variation between major maxima and minima in the dorsal valve of specimen 1 was $7.46^{\circ} \mathrm{C}$ and $3.91^{\circ} \mathrm{C}$ in the ventral valve of specimen 3 .

\section{Table 5.}

\section{Discussion}

\subsection{Comparison of calculated temperatures based on $\mathrm{Mg} / \mathrm{Ca}$ ratios and $\delta^{18} \mathrm{O}$ values}

Average $\mathrm{Mg} / \mathrm{Ca}$ based temperatures calculated from the dorsal and ventral valves of L. rubellus specimens strongly agreed with oxygen isotope derived temperatures recorded in the same shell when using the $\mathrm{Mg} / \mathrm{Ca}$ thermometry equation of Pérez-Huerta 
et al. (2008) and the oxygen isotope paleothermometry equation of Anderson and Arthur (1983) (Tables 2 and 3). When using the equations based on T. retusa and L. neozelanica (Butler et al., 2015), resulting temperatures were significantly higher and lower than the oxygen isotope temperatures, respectively (Tables 2 and 3). This discrepancy shows that species-specific $\mathrm{Mg} / \mathrm{Ca}$ paleothermometry equations do not produce reliable results when used on other species of brachiopods, possibly due to kinetic effects caused by different growth rates between species. However, it is important to note that there are other explanations for this discrepancy, including problems with assumptions regarding $\delta^{18} \mathrm{O}_{\mathrm{w}}$ and habitat.

Average $\mathrm{Mg} / \mathrm{Ca}$ based temperatures calculated from the dorsal and ventral valves of T. terebratula specimens, using the equation of Pérez-Huerta et al. (2008), were within range of the oxygen isotope based temperatures (Tables 2 and 3). The $\mathrm{Mg} / \mathrm{Ca}$ equation of Butler et al. (2015) based on T. retusa produced higher paleotemperatures than the equation of Pérez-Huerta et al. (2008), although these temperatures were also within range of the oxygen isotope based temperatures (Tables 2 and 3). However, the $\mathrm{Mg} / \mathrm{Ca}$ paleothermometry equation of Butler et al. (2015) based on L. neozelanica produced significantly lower temperatures than those calculated using oxygen isotopes (Tables 2 and 3).

\subsection{Comparison of calculated seawater temperatures with previous studies}

The average $\mathrm{Mg} / \mathrm{Ca}$ and oxygen isotope paleotemperatures recorded in specimens of L. rubellus ranged from $8.07^{\circ} \mathrm{C}$ to $12.86^{\circ} \mathrm{C}$ (using the equation after Pérez-Huerta et al. (2008)) and $10.5^{\circ} \mathrm{C}$ to $12.9^{\circ} \mathrm{C}\left(\delta^{18} \mathrm{O}\right)$. These temperature ranges were both lower than those recorded in modern Sagami Bay, Japan, where these fossils originate. Temperatures were compared with modern seawater temperatures because of the lack of paleoclimate data in this location from Pleistocene aged specimens. Seawater temperatures recorded between the years 1976 and 1980 at Sagami Bay at a depth of $75 \mathrm{~m}$ range from $13.12^{\circ} \mathrm{C}$ to $21.34^{\circ} \mathrm{C}$ (Pérez-Huerta et al., 2014). $\mathrm{Mg} / \mathrm{Ca}$ and oxygen isotope paleotemperatures recorded in L. rubellus specimens were slightly cooler than modern seawater temperatures from the same location, but this was expected because of Pleistocene glaciation-inter-glaciation cycles (McClymont et al., 2013). During periods of glaciation, 
$\delta^{18} \mathrm{O}_{\mathrm{w}}$ is greater due to decreased evaporation and more saline seawater. Therefore, the actual Pleistocene paleotemperatures may be slightly greater than those calculated from oxygen isotopes using a $\delta^{18} \mathrm{O}_{\mathrm{w}}$ of $0 \%$ VSMOW.

The average $\mathrm{Mg} / \mathrm{Ca}$ and oxygen isotope paleotemperatures recorded in specimens of T. terebratula ranged from $11.58^{\circ} \mathrm{C}$ to $16.15^{\circ} \mathrm{C}$ (using the equation after Pérez-Huerta et al. (2008)) and $15.7^{\circ} \mathrm{C}$ to $19.7^{\circ} \mathrm{C}\left(\delta^{18} \mathrm{O}\right)$. These values were very similar to paleotemperatures reported from western Mediterranean sea surface during the Late Miocene, which was $16^{\circ} \mathrm{C}$ to $19.5^{\circ} \mathrm{C}$ in the same latitude according to Bosellini and Perrin (2008). During the Messinian the temperature ranges from $13^{\circ} \mathrm{C}$ to $17^{\circ} \mathrm{C}$ in the Sorbas Basin (south Spain) according to Sánchez-Almazo et al. (2001). However, these authors indicate a cooling of Mediterranean waters at the Tortonian-Messinian boundary as detected by $\delta^{18} \mathrm{O}$ record of planktic and benthic foraminifera. The temperatures obtained from Terebratula terebratula of Guadix Basin fit fine with these previous proposals in spite of Guadix Basin was an intra-mountain basin really connected with Atlantic by the narrow straits and the Guadalquivir Basin (see Reolid et al., 2012).

\subsection{Are spiral deviations the result of seasonal growth episodes?}

$\mathrm{Mg} / \mathrm{Ca}$ paleotemperatures resulting from specimens of $L$. rubellus produced seasonal variations at locations of spiral maxima and minima that agreed with seasonal seawater temperature data from a similar modern-day location, although the averages were slightly lower (Tables 3 and 4). These valve-average seasonal temperature variations, which ranged between $3.47^{\circ} \mathrm{C}$ and $9.74^{\circ} \mathrm{C}$, were similar to seasonal seawater temperature variations recorded in modern Sagami Bay, which ranged from $3.40^{\circ} \mathrm{C}$ to $8.22^{\circ} \mathrm{C}$ between the years 1976 and 1980 (Pérez-Huerta et al., 2014). These seasonal variations were also consistent between dorsal and ventral valves within the same specimen (Table 4). However, temperatures recorded at spiral deviations on one valve did not necessarily match those of corresponding deviations on the opposite valve (Table 4). This discrepancy is likely caused by slight error in sampling locations of spiral deviations on the shell during the trace element analysis. Overall, based on the geochemical analyses, spiral deviations in specimens of L. rubellus are interpreted to be the result of seasonal growth episodes. 
Within T. terebratula, a direct relationship between $\mathrm{Mg}$ concentrations and spiral deviations was apparent in the dorsal valve of specimen 1 and the ventral valve of specimen 3, although this relationship was not consistent in all specimens (Table 5). Using the equation by Pérez-Huerta et al. (2008), the dorsal valve of specimen 1 resulted in an average seasonal variation of $7.46^{\circ} \mathrm{C}$ and the ventral valve of specimen 3 resulted in an average seasonal variation of $3.91{ }^{\circ} \mathrm{C}$. The temperature variation recorded in the dorsal valve of specimen 1 was similar to modern day $\left(8-9^{\circ} \mathrm{C}\right)$ and Late Miocene $\left(7.2^{\circ} \mathrm{C}\right)$ seawater temperature variations reported in previous studies of the Mediterranean Sea (Brasseur et al., 1996; Poulos et al., 1997; Mertz-Kraus et al., 2009). Therefore, spiral deviations in the dorsal valve of specimen 1, and possibly those in the ventral valve of specimen 3, were interpreted as the result of seasonal growth episodes.

The absence of a relationship between spiral deviations and $\mathrm{Mg}$ concentrations in other specimens of $T$. terebratula could be attributed to major diagenetic alteration that has not been detected, although all paleotemperatures made biological sense for brachiopod survival and agreed with those from previous studies (Tables 3 and 5). The recrystallized punctae do not represent major diagenetic alteration because the vast majority of the shell is well preserved, but if the sampled material contained secondary calcite, this could alter the resulting $\mathrm{Mg} / \mathrm{Ca}$ ratio and paleotemperature. Another potential explanation is that the shape of shells within this species is not ideal for spiral deviation analysis with the currently developed spiral deviation $\mathrm{R}$ code. In the dorsal valves of $T$. terebratula specimens, there is a flattening in shell shape in the anterior region. Although a second perfect spiral was fit to the biological outline to account for this change in shell shape, there was a large spiral deviation at this location in all specimens, which did not correspond to changes in Mg concentrations. Additionally, the lack of relationship between $\mathrm{Mg}$ concentrations and spiral deviations could be caused by other factors that influence growth, such as spawning, environmental disturbances, or lack of food. These factors could potentially increase or decrease shell growth enough to produce spiral deviations not representative of seasonal growth episodes. Overall, spiral deviations in the dorsal valve of specimen 1 and the ventral valve of specimen 3 were potentially caused by seasonal growth episodes, but spiral deviations in the remaining specimens did not display a strong relationship between seasonality and spiral deviations. 


\subsection{Criteria for "true" spiral deviations and ontogenetic age determinations}

The only species that demonstrated a consistently strong relationship between $\mathrm{Mg}$ concentrations and spiral deviations was $L$. rubellus. Criteria were defined for what constituted "true" spiral deviations that were due to seasonal growth episodes based on the results from the trace element analysis. Based on Mg concentration data from this study, a spiral deviation was deemed seasonal if it was above $0.05 \mathrm{~mm}$ in magnitude. Spiral deviations that did not exceed this value did not demonstrate a measureable change in $\mathrm{Mg}$ concentration. This criterion is similar to the value $(0.025 \mathrm{~mm})$ that was concluded in the study of spiral deviations in modern specimens of L. rubellus (Pérez-Huerta et al., 2014). Resulting ontogenetic ages were as follows: 4 years in specimen 1, 3 years in specimen 2 , and 4 years in specimen 3 . These ontogenetic ages were very similar to those predicted using growth rate studies of modern $L$. rubellus specimens (Yamamoto et al., 2010).

Within the species T. terebratula, only the dorsal valve of specimen 1 and the ventral valve of specimen 3 displayed a relationship between spiral deviations and $\mathrm{Mg}$ concentrations that was interpreted to be due to seasonal growth episodes (Table 5). Based on the trace element analysis, spiral deviations were considered seasonal in these valves if adjacent maxima and minima were both above $0.1 \mathrm{~mm}$ in magnitude. The dorsal valve of $T$. terebratula 1 resulted in an ontogenetic age of 4.5 years and the ventral valve of $T$. terebratula 3 resulted in an ontogenetic age of 4 years, which made biological sense based on their relative sizes and is plausible because the abundance of specimens over the age of five is less than one percent in other species of modern terebratulide brachiopods (e.g., Curry, 1982).

\section{Conclusions}

Two species of fossil brachiopods, including Laqueus and Terebratula, were analyzed to determine if the spiral deviation methodology combined with geochemical proxies is a valid method of determining seasonal seawater temperature variations and ontogenetic ages in fossil specimens. Morphometric analyses revealed that spiral deviation patterns were wide and large in magnitude and produced ontogenetic ages that 
were plausible based on their relative sizes and previous growth rate studies. After determining that shells for both species were relatively well-preserved, a trace element analysis was done at locations of spiral deviations on the shells using LA-ICP-MS. The geochemical analyses revealed that spiral deviations were strongly related to $\mathrm{Mg}$ concentrations in specimens of $L$. rubellus, and resulting $\mathrm{Mg} / \mathrm{Ca}$ paleotemperatures were seasonal. There was a direct relationship between spiral deviations and $\mathrm{Mg}$ concentrations in some specimens of T. terebratula, although the relationship was not consistent in all specimens. Paleotemperatures recorded in specimens of T. terebratula were within the predicted range. Overall, the results from this study indicate that the spiral deviation methodology combined with chemical proxies is a valid method of determining ontogenetic ages and past seasonal seawater temperatures in pristine fossil specimens of L. rubellus and presents great potential for use in other species of fossil brachiopods.

\section{Acknowledgements}

We acknowledge helpful comments and suggestions by Prof. Maria Aleksandra Bitner and an anonymous reviewer, and the help of Dr. Huang Bing. This research was partially funded by the University of Alabama Graduate Student Travel Fund, the DGS Hook's Fund, and the Johnson Travel Fund. We would like to thank J. Goodwin and the staff of the Central Analytical facility at the University of Alabama for their time and assistance with EBSD and SEM analyses. We thank J. Lambert and those working at the Stable Isotope Laboratory at the University of Alabama for their help with oxygen isotope analysis. We also thank C. Garbelli for his helpful review, which improved the quality of this paper. Finally, we greatly appreciate M. Manon at the Union College Geology Department for his immense help with LA-ICP-MS analysis and the US National Science Foundation for funding the instrumentation (NSF-MRI \#1039832 and NSF-CCLI \#9952410). 


\section{References}

Anderson, T.F., Arthur, M.A., 1983. Stable isotopes of oxygen and carbon and their application to sedimentological and paleoenvironmental problems. In: Arthur, M.A., Anderson, T.F., Kaplan, I.R., Veizer, J., Land, L.S. (Eds.), Stable Isotopes in Sedimentary Geology. SEPM Short Course 10, 1-151.

Aldridge, A., Gaspard, D., 2011. Brachiopod life histories from spiral deviations in shell shape and microstructural signature-preliminary report. Memoirs of the Association of Australian Palaeontologists 41, 257-268.

Barbin, V., Gaspard, D., 1995. Cathodoluminescence of recent articulate brachiopod shells: Implications for growth stages and diagenesis evaluation. Geobios (Special Memoir) 18, 39-45.

Bosellini, F., Perrin, C., 2008. Estimating Mediterranean Oligocene-Miocene sea-surface temperatures: An approach based on coral taxonomic richness. Palaeogeography, Palaeoclimatology, Palaeoecology 258, 71-88.

Brand, U., Logan, A., Bitner, M., Griesshaber, E., Azmy, K., Buhl, D., 2011. What is the ideal proxy for Palaeozoic seawater chemistry? Memoirs of the Association of Australasian Palaeontologists 41, 9-24.

Brand, U., Posenato, R., Came, R., Affek, H., Angiolini, L., Azmy, K., Farabegoli, E., 2012. The end-Permian mass extinction: a rapid volcanic $\mathrm{CO}_{2}$ and $\mathrm{CH}_{4}$-climatic catastrophe. Chemical Geology 322-323, 121-144.

Brand, U., Azmy, K., Bitner, M., Logan, A., Zuschin, M., Came, R., Ruggiero, E., 2013. Oxygen isotopes and $\mathrm{MgCO}_{3}$ in brachiopod calcite and a new paleotemperature equation. Chemical Geology 359, 23-31.

Brasseur, P., Beckers, J., Brankart, J., Schoenauen, R., 1996. Seasonal temperature and salinity fields in the Mediterranean Sea: climatological analyses of a historical data set. Deep Sea Research Part 1: Oceanographic Research Papers 43, 159-192.

Butler, S., Bailey, T., Lear, C., Curry, G., Cherns, L., McDonalad, I., 2015. The Mg/Catemperature relationship in brachiopod shells: calibrating a potential paleoseasonality proxy. Chemical Geology 397, 106-117.

Carpenter, S., Lohmann, K.C., 1995. $\delta^{18} \mathrm{O}$ and $\delta^{13} \mathrm{C}$ values of modern brachiopod shells. Geochimica et Cosmochimica Acta 59, 3749-3764. 
Clark, J.V., Aldridge, A.E., Reolid, M., Endo, K., Pérez-Huerta, A., 2015. Application of shell spiral deviation methodology to fossil brachiopods: implications for obtaining specimen ontogenetic ages. Paleontologica Electronica, 18.3.54A, doi: palaeo-electronica.org/content/2015/1189-brachiopod-spiral-deviations.

Curry, G.B., 1982. Ecology and population structure of the Recent brachiopod Terebratulina from Scotland. Palaeontology 25, 227-246.

Curry, G.B., Fallick, A., 2002. Use of stable oxygen isotope determinations from brachiopod shells in palaeoenvironmental reconstruction. Palaeogeography, Palaeoclimatology, Palaeoecology 182, 133-143.

Cusack, M., Dauphin, Y., Cuif, J.P., Salome, M., Freer, A., Yin, H., 2008. Micro XANES mapping of sulphur and its association with magnesium and phosphorous in the shell of the brachiopod, Terebratulina retusa. Chemical Geology 253, 172-179.

Dettman, D.L., Reische, A.K., Lohmann, K.C., 1999. Controls on the stable isotope composition of seasonal growth bands in aragonitic fresh-water bivalves (unionidae). Geochimica et Cosmochimica Acta 63, 1049-1057.

Endo, K., 1987. Life habit and relative growth of some Laqueid brachiopods from Japan. Transactions and Proceeding of the Palaeontological Society of Japan 147, 180194.

Epstein, S., Buchbaum, H., Lowenstam, H., 1953. Revised carbonate-water isotopic temperature scale. Bulletin of the Geological Society of America 64, 1315-1326.

Findlater, G., Shelton, A., Rolin, T., Andrews, J., 2014. Sodium and strontium in mollusc shells: preservations, palaeosalinity and palaeotemperature of the Middle Pleistocene of eastern England. Proceedings of the Geologists' Association 125, 14-19.

Garbelli, C., Angiolini, L., Brand, U., Shen, S.Z., Jadoul, F., Posenato, R., Azmy, K., Cao, C.Q., in press. Neotethys seawater chemistry and temperature at the dawn of the latest Permian extinction. Gondwana Research, doi: 10.1016/j.gr.2015.05.012.

Geldern, R., Joachimski, M., Day, J., Jansen, U., Alvarez, F., Yolkin, E.A., Ma, X., 2006. Carbon, oxygen and strontium isotope records of Devonian brachiopod shell calcite. Palaeogeography, Palaeoclimatology, Palaeoecology 240, 47-67. 
Gentleman, R., Ihaka, R., 1997. R [Computer Software]. University of Auckland, Auckland, New Zealand. Retrieved February 17, 2015. Available from http://www.r-project.org

Giles, P., 2012. Low-latitude Ordovician to Triassic brachiopod habitat temperatures (BHTs) determined from $\delta^{18} \mathrm{O}_{\text {[brachiopod calcite] }}$ A cold hard look at ice-house tropical oceans. Palaeogeography, Palaeoclimatology, Palaeoecology 317-318, $134-152$.

Gillikin, D.P., Dehairs, F., 2013. Uranium in aragonitic bivalve shells. Palaeogeography, Palaeoclimatology, Palaeoecology 373, 60-65.

Ivany, L.C., 2012. Reconstructing paleoseasonality from accretionary skeletal carbonates — challenges and opportunities. The Paleontological Society Papers 18, 133-165.

Ivany, L.C., Wilkinson, B.H., Lohmann, K.C., Johnson, E.R., McElroy, B.J., Cohen, G.J., 2004. Intra-annual isotopic variation in Venericardia bivalves: Implications for early Eocene temperature, seasonality, and salinity on the US Gulf Coast. Journal of Sedimentary Research 74, 7-19.

Klein, R.T., Lohmann, K.C., Thayer, C.W., 1996. Bivalve skeletons record sea-surface temperature and delta $\mathrm{O}-18$ via $\mathrm{Mg} / \mathrm{Ca}$ and $\mathrm{O}-18 / \mathrm{O}-16$ ratios. Geology 24, 415418.

Lee, X.Q., Hu, R.Z., Brand, U., Zhou, H., Liu, X.M., Yuan, H.L., Yan, C.L., Cheng, H.G., 2004. Ontogenetic trace element distribution in brachiopod shells: an indicator of original seawater chemistry. Chemical Geology 209, 49-65.

Linnaeus, C., 1758. Systema Naturae per Regna Tria Naturae, Secundum Classes, Ordines, Genera, Species, cum Characteribus, Differentiis, Synonymis, Locis. Lugduni Batavorum, Leiden.

McClymont, E., Sosdian, S., Rosell-Melé, A., Rosenthal, Y., 2013. Pleistocene seasurface temperature evolution: early cooling, delayed glacial intensification, and implications for the mid-Pleistocene climate transition. Earth-Science Reviews 123, 173-193.

Mertz-Kraus, R., Brachert, T., Reuter, M., Galer, S., Fassoulas, C., Iliopoulos, G., 2009. Late Miocene sea surface salinity variability and paleoclimate conditions in the 
Eastern Mediterranean inferred from coral aragonite $\delta^{18} \mathrm{O}$. Chemical Geology 262, 202-216.

Mii, H.S., Shi, G.R., Cheng, C.J., Chen, Y.Y., 2012. Permian Gondwanaland paleoenvironment inferred from carbon and oxygen isotope records of brachiopods from Sydney Basin, southeast Australia. Chemical Geology 291, 87103.

Parkinson, D., Curry, G., Cusack, M., Fallick, A., 2005. Shell structure, patterns and trends of oxygen and carbon stable isotopes in modern brachiopod shells. Chemical Geology 219, 193-235.

Pearce, N., Perkins, W., Westgate, J., Gorton, M., Jackson, S., Neal, C., Chenery, S., 1997. A compilation of new and published major and trace element data for NIST SRM 610 and NIST SRM 612 glass reference materials. Geostandards Newsletter 21, 115-144.

Pérez-Huerta, A., Cusack, M., Jeffries, T., Williams, C., 2008. High resolution distribution of magnesium and strontium and the evaluation of $\mathrm{Mg} / \mathrm{Ca}$ thermometry in Recent brachiopod shells. Chemical Geology 247, 229-241.

Pérez-Huerta, A., Aldridge, A., Endo, K., Jeffries, T., 2014. Brachiopod shell spiral deviations (SSD): Implications for trace element proxies. Chemical Geology 374375, 13-24.

Poulos, S., Drakopoulos, P., Collins, M., 1997. Seasonal variability in sea surface oceanographic conditions in the Aegean Sea (Eastern Mediterranean): an overview. Journal of Marine Science 13, 225-244.

Powell, M., Schone, B., Jacob, D., 2009. Tropical marine climate during the late Paleozoic ice age using trace element analyses of brachiopods. Palaeogeography, Palaeoclimatology, Palaeoecology 280, 143-149.

Reolid, M., García-García, F., Tomašových, A., Soria, J., 2012. Thick brachiopod shell concentrations from prodelta and siliciclastic ramp in a Tortonian AtlanticMediterranean strait (Miocene, Guadix Basin, southern Spain). Facies 58, 549-571.

Roark, A., Grossman, E., Lebold, J., 2016. Low seasonality in central equatorial Pangea during a late Carboniferous highstand based on high-resolution isotopic records of brachiopod shells. Geological Society of America Bulletin 128, 597-608. 
Sánchez-Almazo, I.M., Spiro, B., Braga, J.C., Martín, J.M., 2001. Constraints of stable isotope signatures on the depositional palaeoenvironments of upper Miocene reef and temperate carbonates in the Sorbas Basin, SE Spain. Palaeogeography, Palaeoclimatology, Palaeoecology 175, 153-172.

Schmahl, W., Griesshaber, E., Kelm, K., Goetz, A., Jordan, G., Ball, A., Xu, D., Merkel, C., Brand, U., 2012. Hierarchical structure of marine shell biomaterials: biomechanical functionalization of calcite by brachiopods. Crystalline Materials 227, 793-804.

Sowerby, G.B., 1846. Description of Tertiary fossil shells from South America. In: Darwin, C.R. (Ed.), Geological Observations on South America. Smith, Elder and Co., Cornhill, pp. 249-264.

Suan, G., Mattioli, E., Pittet, B., Mailliot, S., Lécuyer, C., 2008. Evidence for major environmental perturbation prior to and during the Toarcian (Early Jurassic) oceanic anoxic event from the Lusitanian Basin, Portugal. Paleoceanography 23, PA1202, doi: 10.1029/2007PA001459.

Surge, D., Lohmann, K.C., 2008. Evauating Mg/Ca ratios as a temperature proxy in the estuarine oyster, Crassostrea virginica. Journal of Geophysical ResearchBiogeosciences 113, G02001, doi: 10.1029/2007JG000623.

Surge, D., Lohmann, K.C., Dettman, D.L., 2001. Controls on isotopic chemistry of the American oyster, Crassostrea virginica: implications for growth patterns.

Palaeogeography, Palaeoclimatology, Palaeoecology 172, 283-296.

Thayer, C., 1977. Recruitment, growth, and mortality of a living brachiopod, with implications for the interpretation of survivorship curves. Paleobiology 3, 98-109.

Veizer, J., Fritz, P., Jones, B., 1986. Geochemistry of brachiopods: Oxygen and carbon isotopic records of Paleozoic oceans. Geochimica et Cosmochimica Acta 50, 16791696.

Williams, M., Haywood, A., Taylor, S., Valdes, P., Sellwood, B., Hillenbrand, C., 2005. Evaluating the efficacy of planktonic foraminifera calcite $\delta^{18} \mathrm{O}$ data for sea surface temperature reconstruction for the Late Miocene. Geobios 38, 848-863. 
Yamamoto, K., Asami, R., Iryu, Y., 2010. Carbon and oxygen isotopic compositions of modern brachiopod shells from a warm-temperature shelf environment, Sagami Bay, central Japan. Palaeogeography, Palaeoclimatology, Palaeoecology 291, 348-359.

\section{Figure captions}

Fig. 1. Ventral, dorsal, posterior, and longitudinal-sectional views of the fossil brachiopods Laqueus rubellus and Terebratula terebratula. Scale bar $=1 \mathrm{~cm}$ [Figure modified and adapted from fig. 1 in Clark et al. (2015), with permission from Palaeontologia Electronica (palaeo-electronica.org)].

Fig. 2. Example of shell (Laqueus rubellus) digitization and spiral fitting. (A) The brachiopod shell was digitized by clicking the outline in an anterior-ward direction, starting at the umbo. (B) The digitized outline was saved as (x,y) coordinates, which were used to plot a biological outline in R. (C) R code was used to fit a perfect logarithmic spiral to the shell outline. (D) The deviations from a perfect spiral were represented in a spiral deviation graph, with green points representing spiral maxima and red points representing spiral minima [Figure modified and adapted from fig. 3 in Clark et al. (2015), with permission from Palaeontologia Electronica (palaeo-electronica.org)].

Fig. 3. Sampling methodology for oxygen isotope analysis using a micromill, and for trace $(\mathrm{Mg})$ elements using a LA-ICP-MS.

Fig. 4. SEM images of the dorsal and ventral valves of Laqueus rubellus 1. Note: Arrow in (B) points to the contact between transversely and longitudinally cut calcite fibers.

Fig. 5. EBSD data of the dorsal and ventral valves of Laqueus rubellus 1. (A and D) Diffraction maps; (B and E) crystallographic maps, with colors corresponding to the 
calcite crystallographic planes as represented in the color-key in G; (C and F) pole figures of crystallographic planes projected on the $\{0001\}$ plane of calcite.

Fig. 6. SEM images of the dorsal and ventral valves of Terebratula terebratula 2. Note: Arrows points to punctae, which are in-filled with secondary calcite.

Fig. 7. EBSD data of the dorsal and ventral valves of Terebratula terebratula 1. (A and D) Diffraction maps; (B and E) crystallographic maps, with colors corresponding to the calcite crystallographic planes as represented in the color-key in $\mathrm{G}$; (C and F) pole figures of crystallographic planes projected on the $\{0001\}$ plane of calcite.

Fig. 8. Example of Mg concentrations at locations of spiral deviations on a shell of Laqueus rubellus.

Fig. 9. Example of $\mathrm{Mg}$ concentrations at locations of spiral deviations on a shell of Terebratula terebratula. 


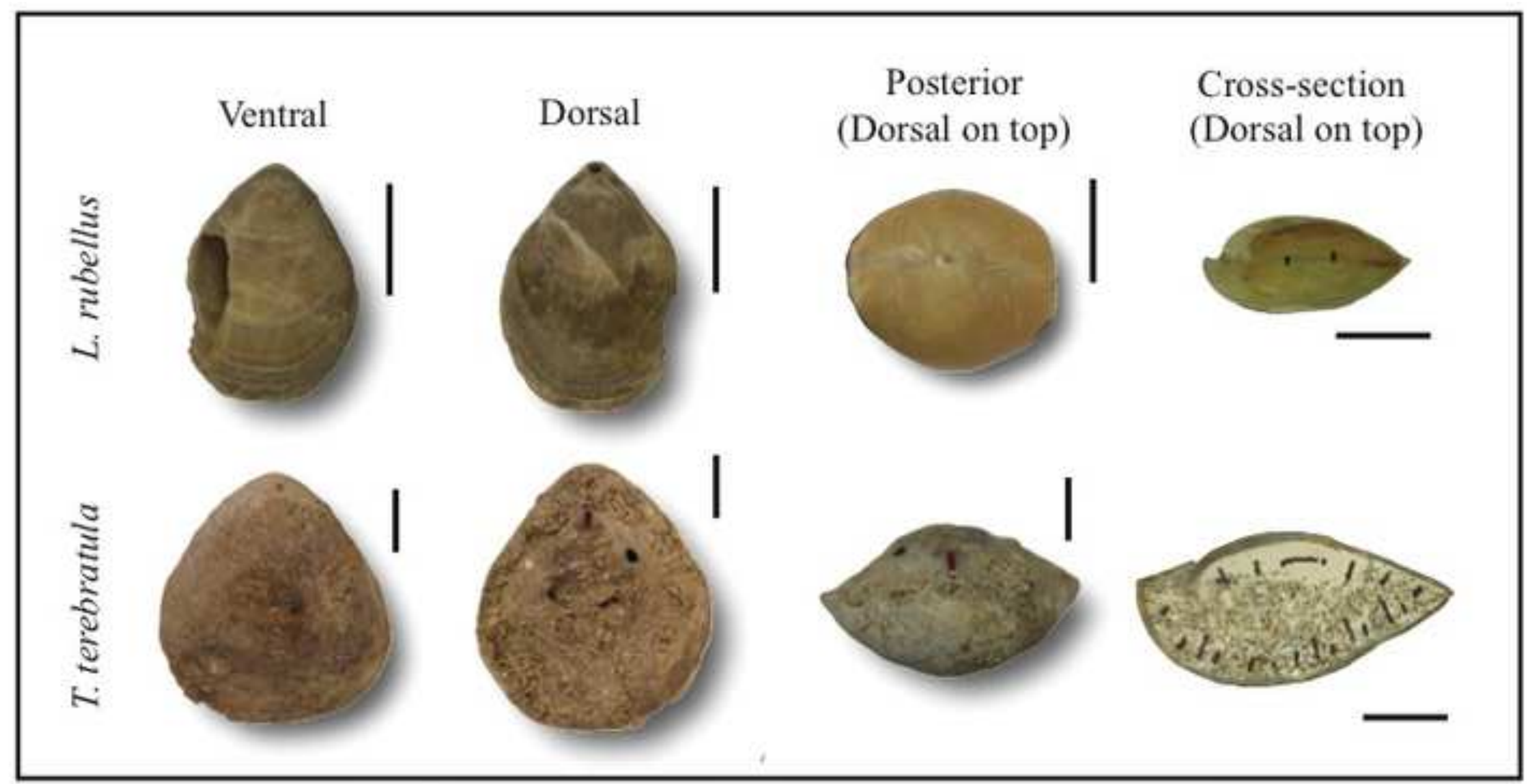




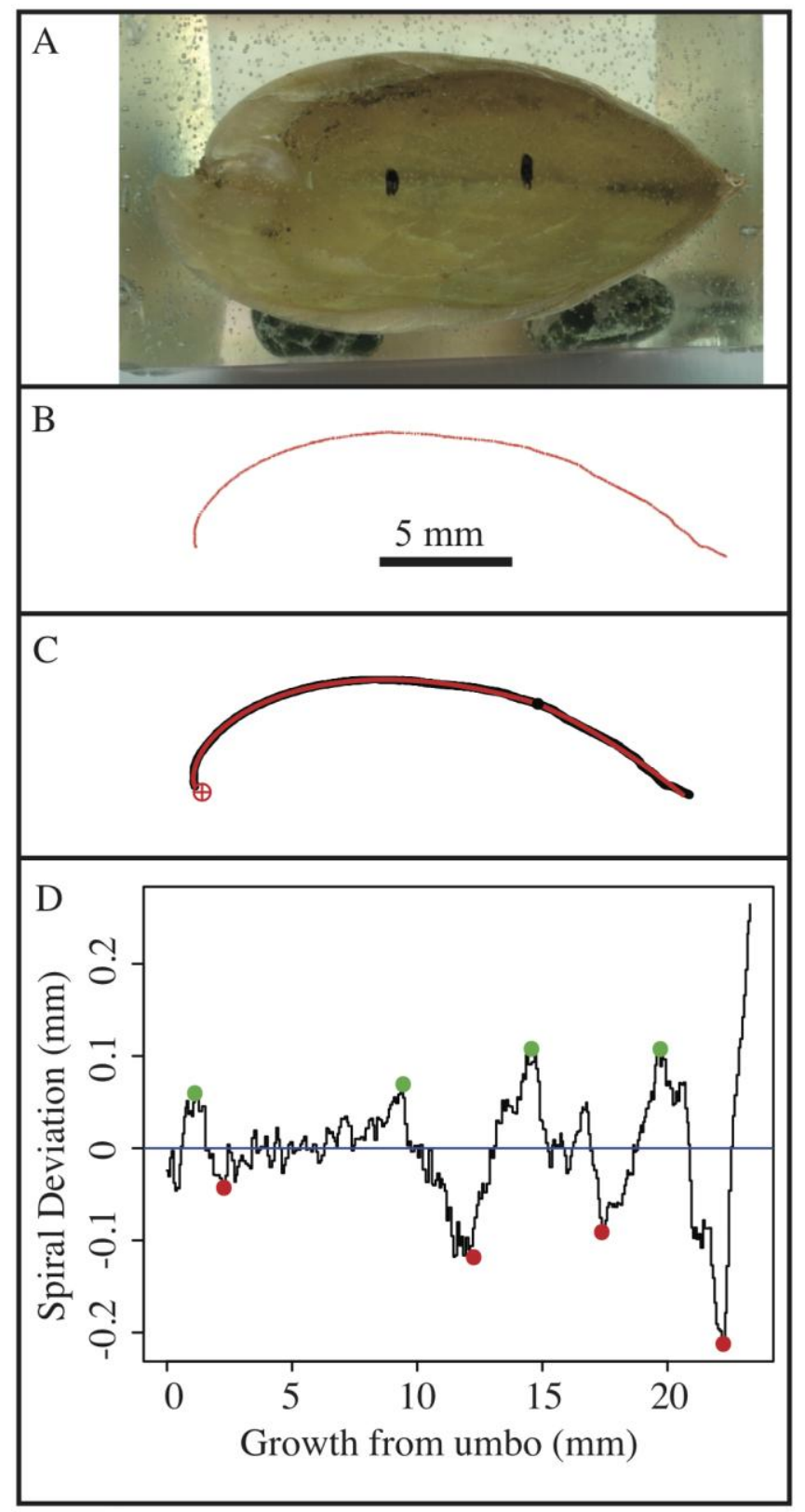




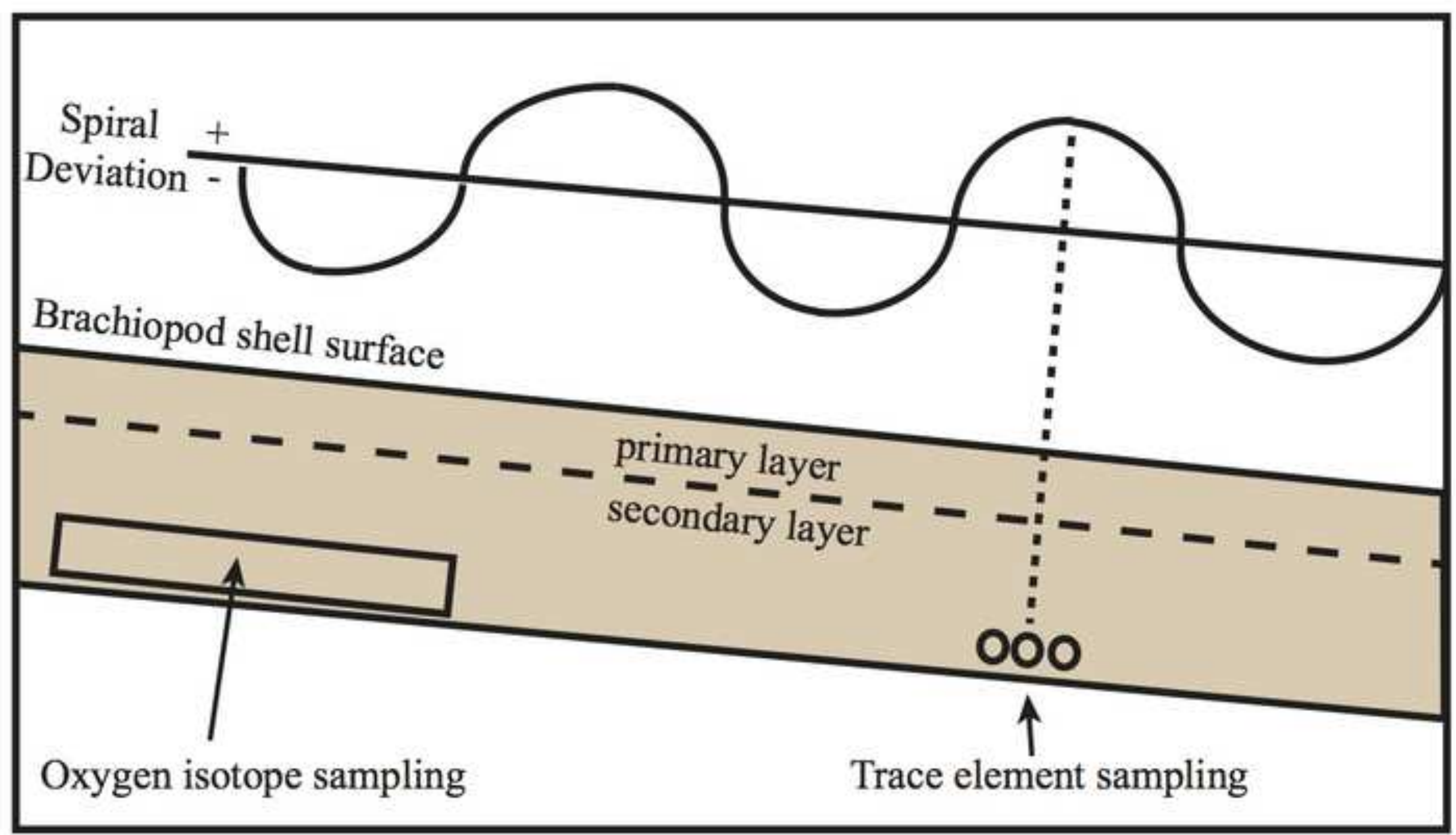




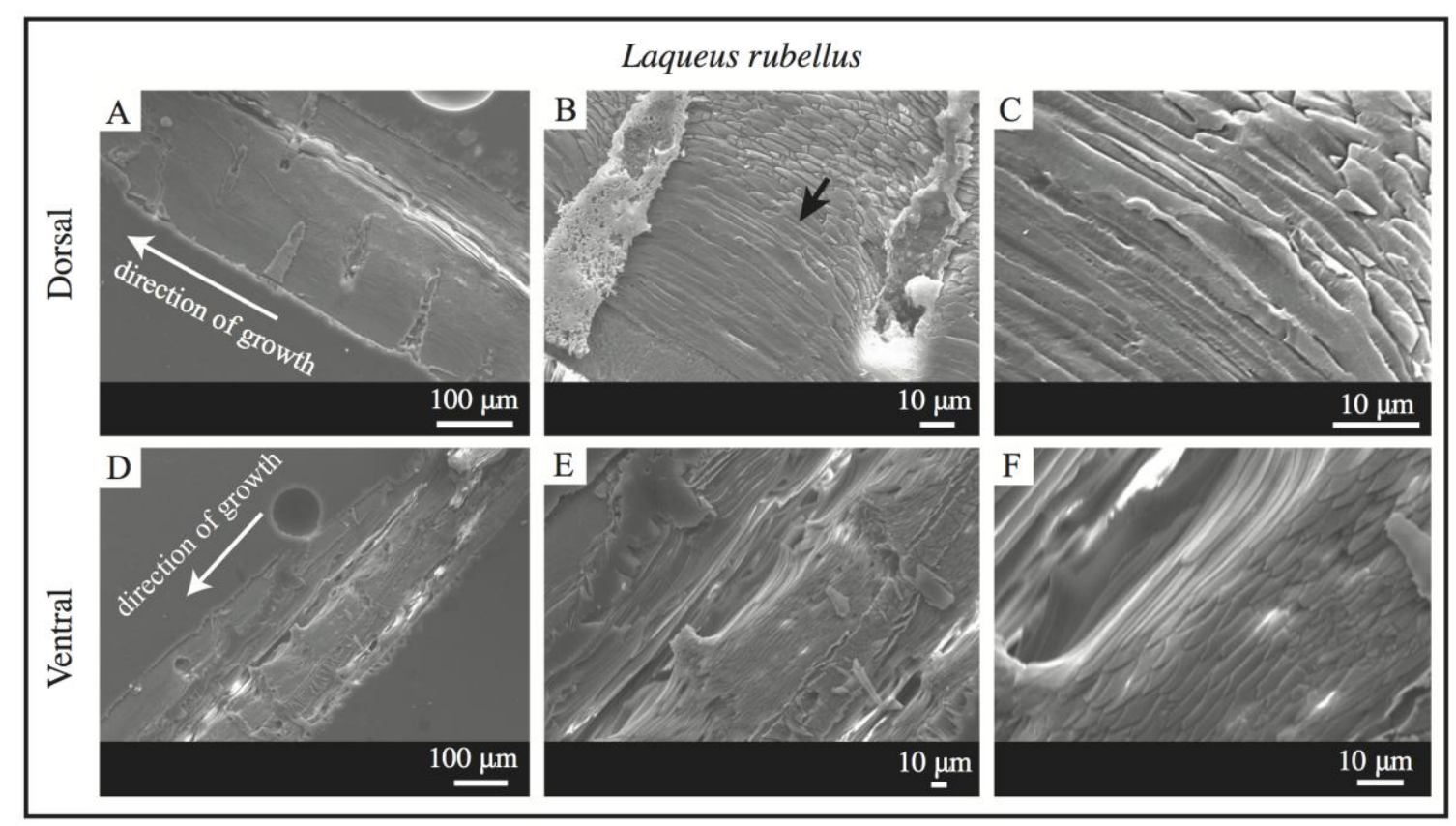




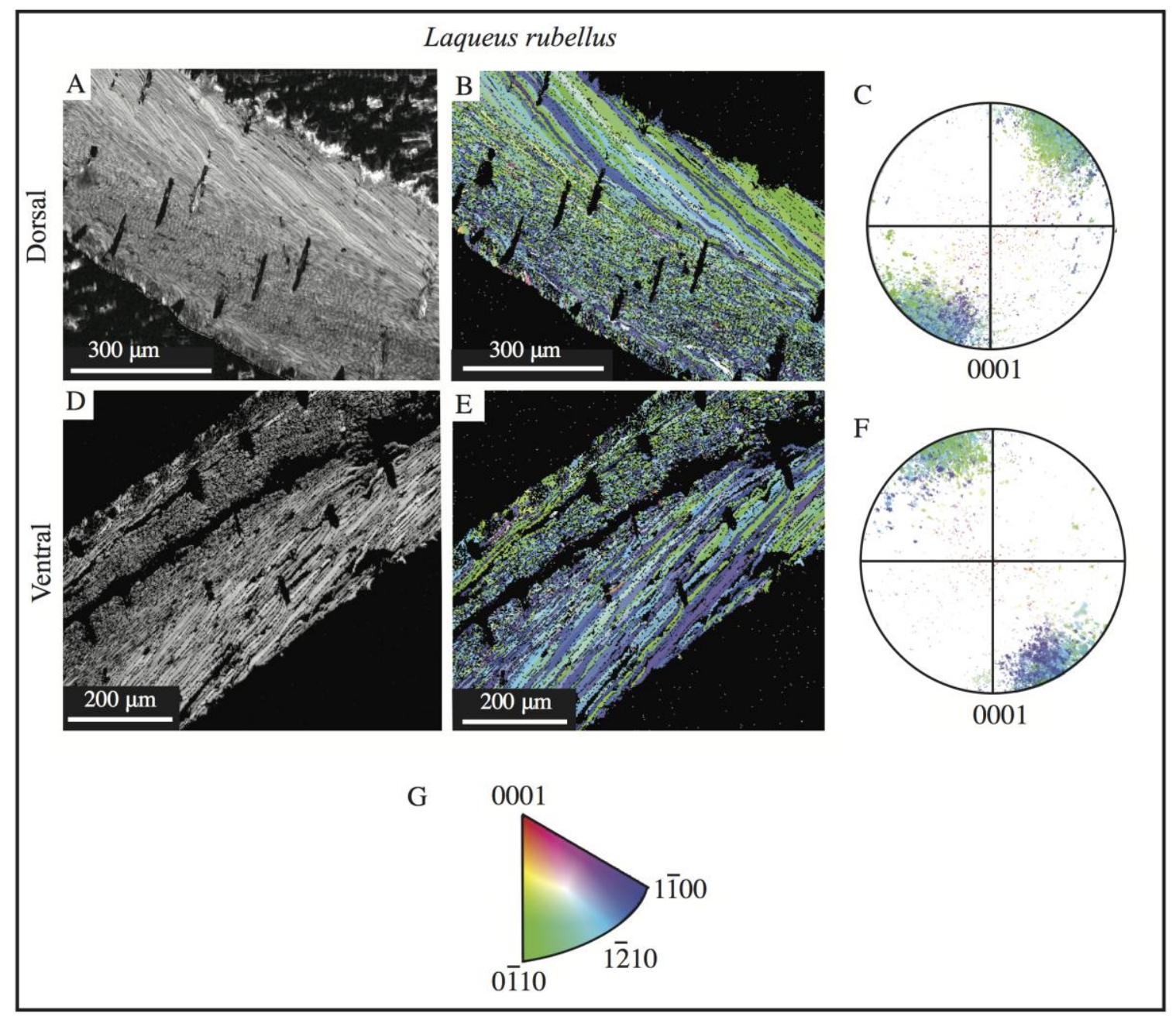




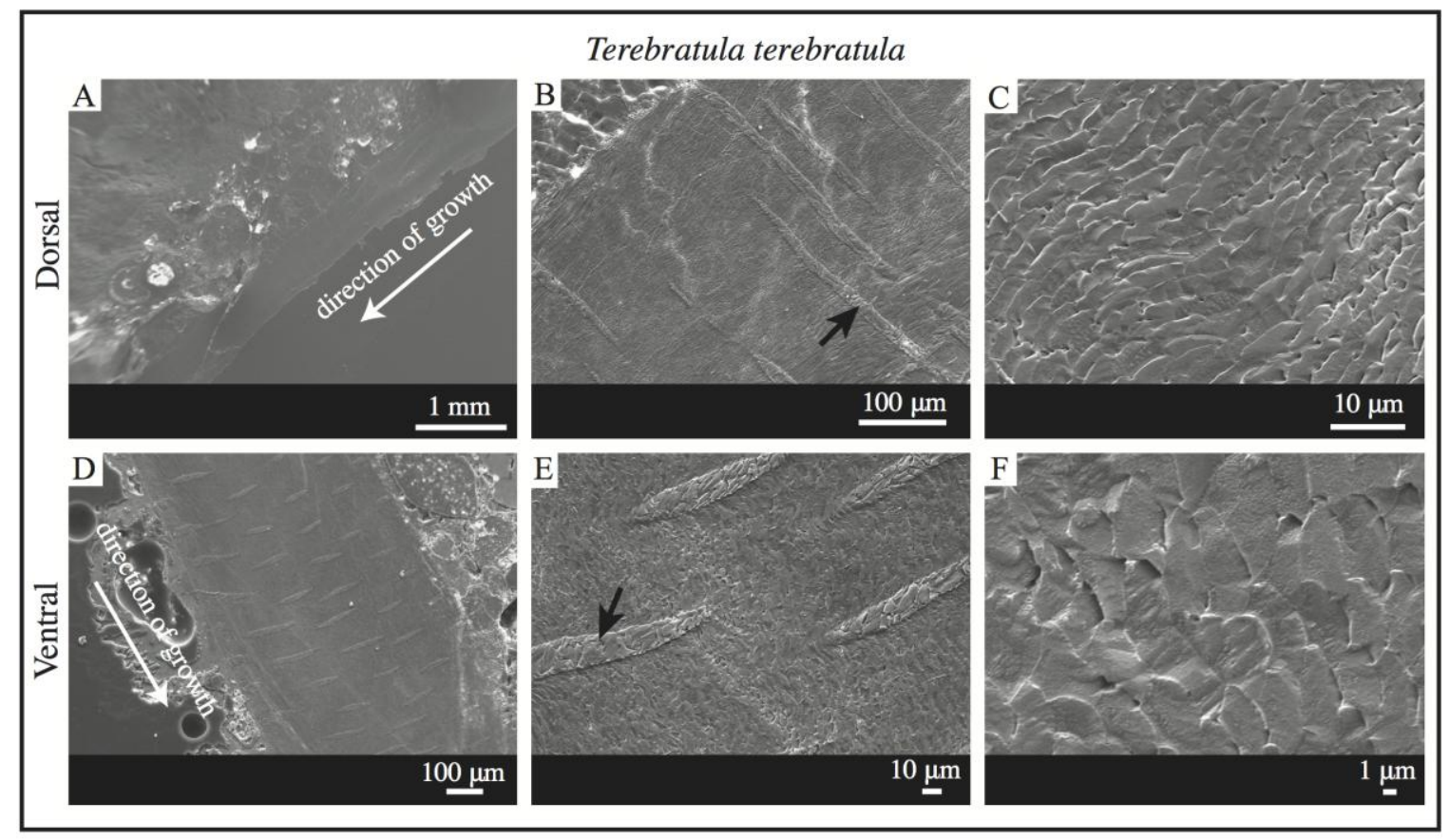




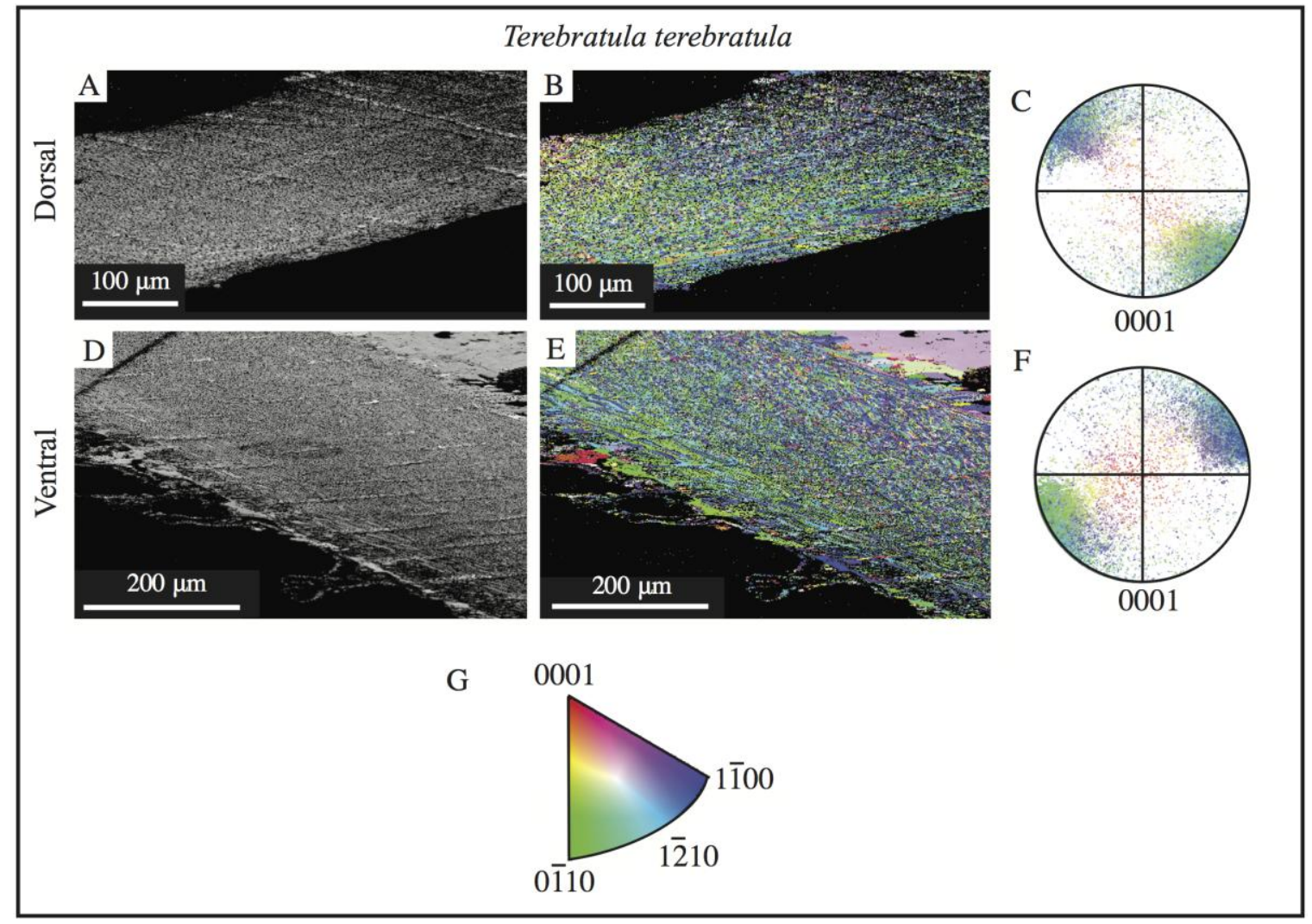




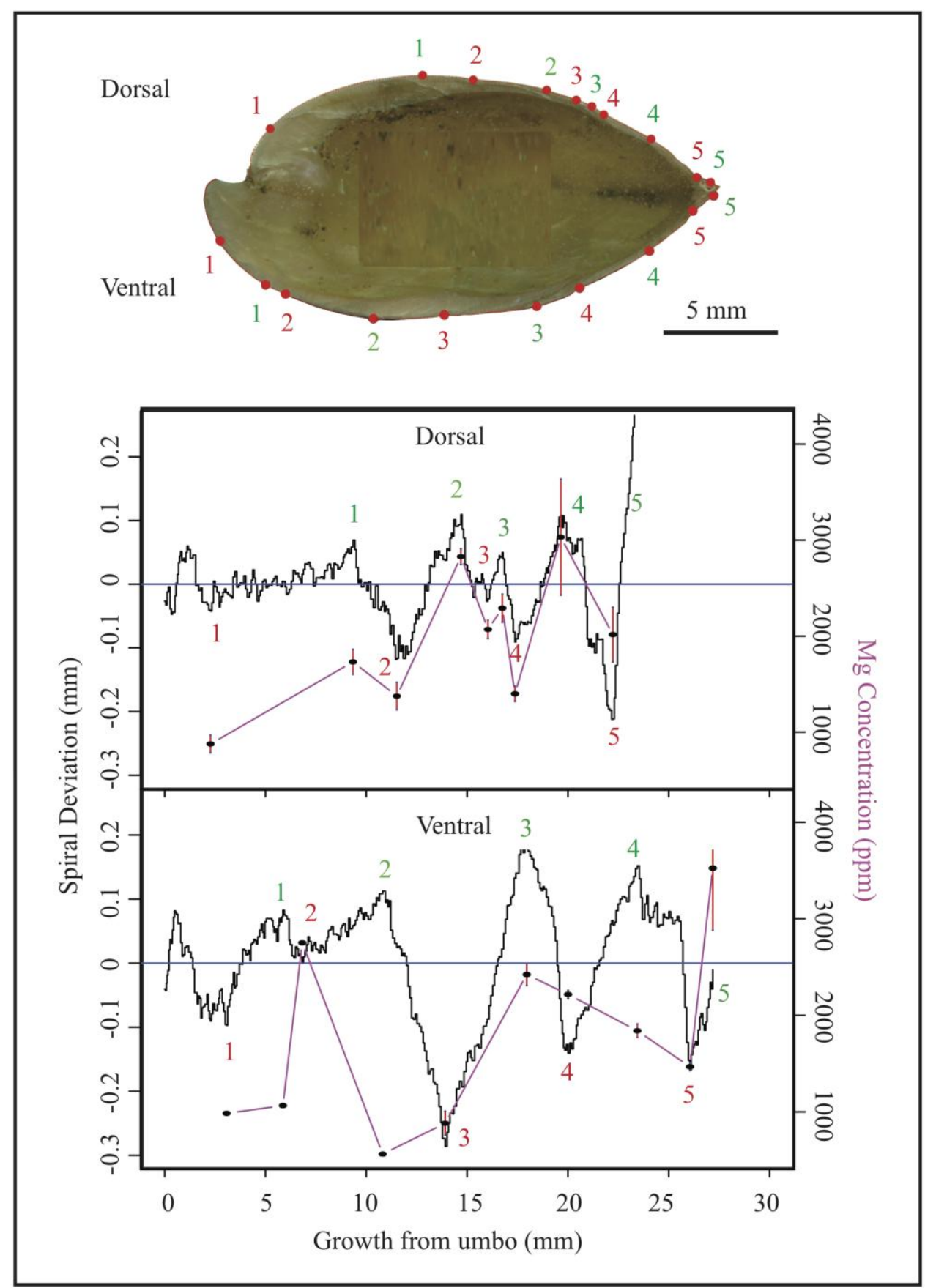




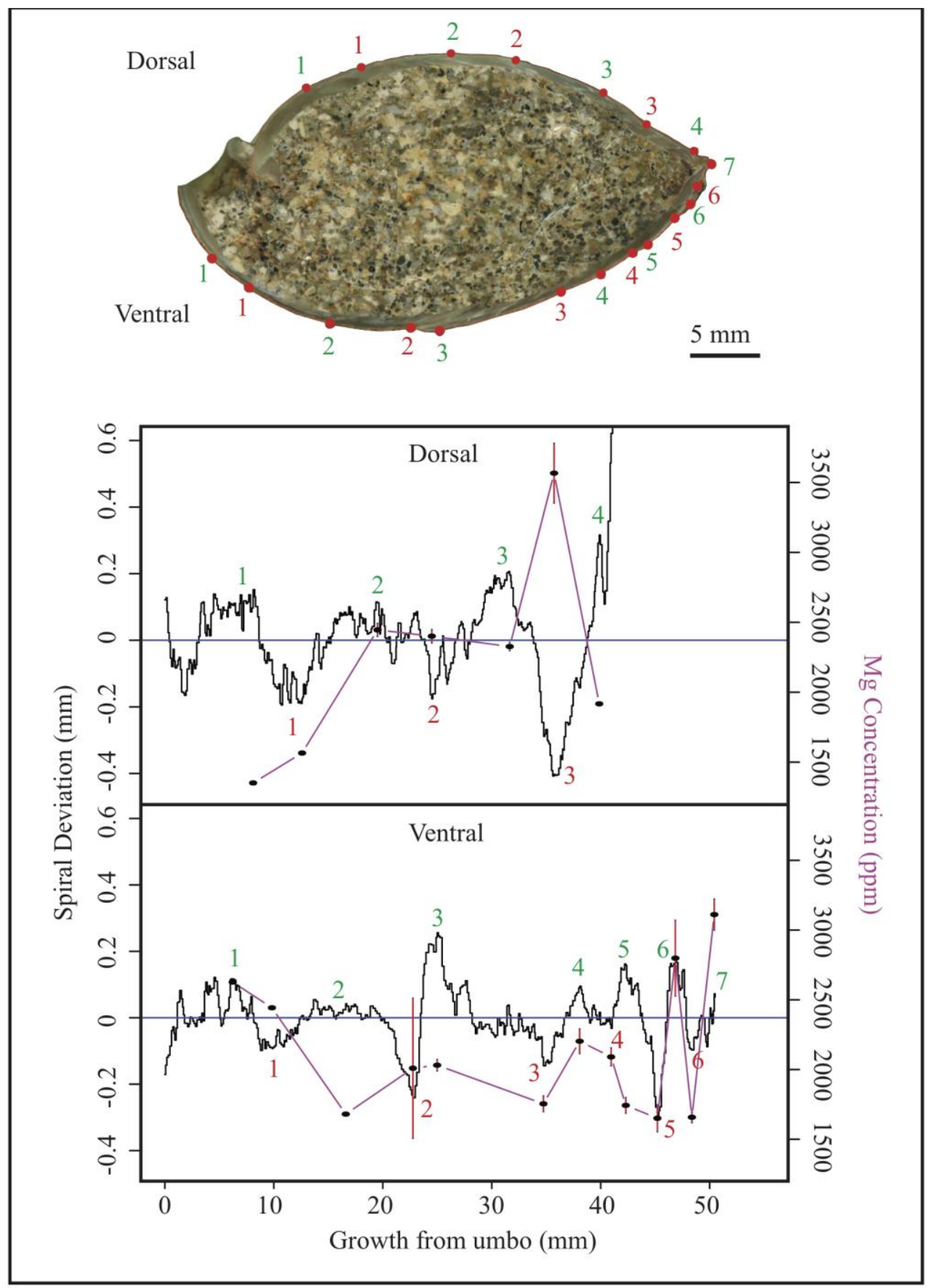




\begin{tabular}{|c|c|c|c|c|c|c|c|}
\hline Specimen & $\begin{array}{c}\text { Length } \\
(\mathbf{m m})\end{array}$ & Width $\mathbf{( m m )}$ & $\begin{array}{c}\text { Thickness } \\
(\mathbf{m m})\end{array}$ & $\begin{array}{c}\text { Dorsal } \\
\text { minima }\end{array}$ & $\begin{array}{c}\text { Dorsal } \\
\text { maxima }\end{array}$ & $\begin{array}{c}\text { Ventral } \\
\text { minima }\end{array}$ & $\begin{array}{c}\text { Ventral } \\
\text { maxima }\end{array}$ \\
\hline L. rubellus 1 & 23.2 & 14.8 & 10.5 & 4 & 4 & 4 & 4 \\
\hline L. rubellus 2 & 29.3 & 19.0 & 17.0 & 2 & 3 & 3 & 3 \\
\hline L. rubellus 3 & 27.1 & 18.0 & 14.0 & 2 & 3 & 2 & 3 \\
\hline T. terebratula 1 & 47.3 & 34.0 & 24.5 & 5 & 6 & 3 & 4 \\
\hline T. terebratula 2 & 38.7 & 34.2 & 18.9 & 4 & 3 & 4 & 4 \\
\hline T. terebratula 3 & 40.4 & 32.0 & 21.9 & 4 & 4 & 3 & 4 \\
\hline
\end{tabular}

Table 1. Size measurements (length, width, and thickness) and spiral deviations from all analyzed specimens of the species Laqueus rubellus and Terebratula terebratula. Modified after Clark et al. (2015). 


\begin{tabular}{|c|c|c|c|c|}
\hline Specimen & $\boldsymbol{\delta}^{\mathbf{1 8}} \mathbf{O}_{\text {Dorsal }}$ & $\boldsymbol{\delta}^{\mathbf{1 8}} \mathbf{O}_{\text {Ventral }}$ & $\mathbf{T}_{\text {Dorsal }}$ & $\mathbf{T}_{\text {Ventral }}$ \\
\hline L. rubellus 1 & $0.7 \pm 0.2$ & $0.7 \pm 0.3$ & $12.8 \pm 0.8$ & $12.9 \pm 1.1$ \\
L. rubellus 2 & $0.8 \pm 0.2$ & $1.2 \pm 0.2$ & $12.5 \pm 0.9$ & $11.1 \pm 0.7$ \\
L. rubellus 3 & $0.9 \pm 0.4$ & $1.3 \pm 0.2$ & $12.3 \pm 1.5$ & $10.5 \pm 0.8$ \\
T. terebratula 1 & $-0.1 \pm 0.6$ & $0.1 \pm 0.4$ & $16.3 \pm 2.5$ & $15.7 \pm 0.2$ \\
T. terebratula 2 & $-0.5 \pm 0.6$ & $-0.7 \pm 0.5$ & $18.2 \pm 2.8$ & $19.1 \pm 2.3$ \\
T. terebratula 3 & $-0.8 \pm 0.9$ & $-0.7 \pm 3.2$ & $19.7 \pm 4.0$ & $19.4 \pm 3.3$ \\
\hline
\end{tabular}

Table 2. Average $\delta^{18} \mathrm{O}(\% \mathrm{VSMOW})$ values and temperatures $\left({ }^{\circ} \mathrm{C}\right)$ from the dorsal and ventral valves of Laqueus rubellus and Terebratula terebratula. T are temperatures resulting from the oxygen isotope thermometry equation of Epstein et al. (1953) modified by Anderson and Arthur (1983). $\delta^{18} \mathrm{O}_{\mathrm{w}}$ values are assumed to be 0 (\%o VSMOW) in Laqueus rubellus and Terebratula terebratula. 


\begin{tabular}{|c|c|c|c|c|c|c|c|c|}
\hline Specimen & $\begin{array}{c}\text { Mg/Ca } \\
\text { al }\end{array}$ & $\begin{array}{c}\mathrm{Mg} / \mathrm{Ca}_{\text {Vent }} \\
\text { ral }\end{array}$ & $\mathbf{T}_{\text {Dorsal }}{ }^{1}$ & $\mathbf{T}_{\text {Ventral }}{ }^{1}$ & $\mathbf{T}_{\text {Dorsal }}{ }^{2}$ & $\mathbf{T}_{\text {Ventral }}{ }^{2}$ & $\mathbf{T}_{\text {Dorsal }}{ }^{3}$ & $\mathbf{T}_{\text {Ventral }}{ }^{3}$ \\
\hline L. rubellus $1 *$ & $8.61 \pm 3.05$ & $7.77 \pm 4.18$ & $12.86 \pm 4.12$ & $11.72 \pm 5.70$ & $19.64 \pm 3.21$ & $17.58 \pm 5.45$ & $9.00 \pm 2.01$ & $7.91 \pm 3.03$ \\
\hline L. rubellus 2 & $8.49 \pm 2.92$ & $7.86 \pm 3.25$ & $12.67 \pm 3.99$ & $11.74 \pm 4.52$ & $19.66 \pm 2.71$ & $18.14 \pm 4.71$ & $8.97 \pm 1.78$ & $8.14 \pm 2.81$ \\
\hline L. rubellus 3 & $5.41 \pm 1.59$ & $5.17 \pm 2.50$ & $8.48 \pm 2.17$ & $8.07 \pm 3.32$ & $16.14 \pm 2.35$ & $14.39 \pm 5.49$ & $6.75 \pm 1.41$ & $6.02 \pm 2.83$ \\
\hline T. terebratula 1 & $8.43 \pm 3.21$ & $9.83 \pm 1.46$ & $11.58 \pm 3.88$ & $14.70 \pm 1.10$ & $19.52 \pm 2.99$ & $21.40 \pm 0.87$ & $8.89 \pm 2.00$ & $10.10 \pm 0.61$ \\
\hline T. terebratula 2 & $10.74 \pm 2.64$ & $10.06 \pm 1.93$ & $16.15 \pm 3.49$ & $14.41 \pm 1.85$ & $21.89 \pm 1.83$ & $21.12 \pm 0.93$ & $10.46 \pm 1.27$ & $9.91 \pm 0.65$ \\
\hline T. terebratula $3 *$ & $10.71 \pm 2.84$ & $9.33 \pm 2.24$ & $14.69 \pm 4.45$ & $14.18 \pm 2.89$ & $20.92 \pm 2.48$ & $20.86 \pm 1.65$ & $9.80 \pm 1.69$ & $9.74 \pm 1.14$ \\
\hline
\end{tabular}

Table 3. Average $\mathrm{Mg} / \mathrm{Ca}$ ratios $(\mathrm{mmol} / \mathrm{mol})$ and temperatures $\left({ }^{\circ} \mathrm{C}\right)$ from the anterior regions of the dorsal and ventral valves of Laqueus rubellus and Terebratula terebratula. $\mathrm{T}^{1}$ are temperatures resulting from the $\mathrm{Mg} / \mathrm{Ca}$ paleothermometry equation by PérezHuerta et al. (2008) based on modern brachiopods, $\mathrm{T}^{2}$ are temperatures resulting from the equation by Butler et al. (2015) based on the modern brachiopod Terebratulina retusa, and $\mathrm{T}^{3}$ are temperatures resulting from the equation by Butler et al. (2015) based on the modern brachiopod Liothyrella neozelanica. * Indicates that the posterior and anterior regions of the shell were analyzed for $\mathrm{Mg} / \mathrm{Ca}$ ratios and temperatures. 


\begin{tabular}{|c|c|c|c|c|c|}
\hline Specimen & Deviation & $\mathrm{Mg} / \mathrm{Ca}(\mathrm{mmol} / \mathrm{mol})$ & $T^{1}$ & $\mathbf{T}^{2}$ & $\mathbf{T}^{3}$ \\
\hline 1 Dorsal & $1 \mathrm{~min}$ & $3.85 \pm 0.40$ & $6.35 \pm 0.55$ & $12.72 \pm 1.21$ & $4.84 \pm 0.60$ \\
\hline 1 Dorsal & $1 \max$ & $7.32 \pm 0.17$ & $11.48 \pm 0.72$ & $19.21 \pm 0.55$ & $8.61 \pm 0.37$ \\
\hline 1 Dorsal & $2 \min$ & $6.40 \pm 0.18$ & $9.34 \pm 0.86$ & $17.23 \pm 0.96$ & $7.36 \pm 0.58$ \\
\hline 1 Dorsal & $2 \max$ & $12.43 \pm 0.35$ & $19.03 \pm 1.73$ & $23.36 \pm 0.68$ & $11.48 \pm 0.49$ \\
\hline 1 Dorsal & $3 \min$ & $6.15 \pm 0.35$ & $9.49 \pm 0.48$ & $18.94 \pm 2.65$ & $8.48 \pm 1.76$ \\
\hline 1 Dorsal & $3 \max$ & $13.33 \pm 2.66$ & $16.75 \pm 5.06$ & $22.07 \pm 2.53$ & $10.59 \pm 1.76$ \\
\hline 1 Dorsal & $4 \mathrm{~min}$ & $8.87 \pm 1.25$ & $13.19 \pm 1.71$ & $20.37 \pm 1.14$ & $9.39 \pm 0.77$ \\
\hline 2 Dorsal & $1 \max$ & $12.32 \pm 0.14$ & $17.90 \pm 0.19$ & $22.92 \pm 0.08$ & $11.16 \pm 0.06$ \\
\hline 2 Dorsal & $2 \min$ & $4.78 \pm 0.20$ & $7.61 \pm 0.28$ & $15.07 \pm 0.42$ & $6.08 \pm 0.24$ \\
\hline 2 Dorsal & $2 \max$ & $13.19 \pm 1.74$ & $19.09 \pm 2.37$ & $23.38 \pm 0.95$ & $11.49 \pm 0.69$ \\
\hline 2 Dorsal & $3 \mathrm{~min}$ & $6.46 \pm 0.28$ & $9.90 \pm 0.38$ & $17.85 \pm 0.37$ & $7.73 \pm 0.23$ \\
\hline 3 Dorsal & $1 \max$ & $5.29 \pm 1.12$ & $8.32 \pm 1.52$ & $16.97 \pm 1.07$ & $7.20 \pm 0.65$ \\
\hline 3 Dorsal & $1 \mathrm{~min}$ & $3.65 \pm 0.64$ & $6.07 \pm 0.88$ & $13.23 \pm 0.61$ & $5.09 \pm 0.31$ \\
\hline 3 Dorsal & $2 \max$ & $8.28 \pm 0.19$ & $12.38 \pm 0.25$ & $19.90 \pm 0.18$ & $9.07 \pm 0.12$ \\
\hline 1 Ventral & $1 \mathrm{~min}$ & $4.33 \pm 0.00$ & $7.00 \pm 0.00$ & $14.09 \pm 0.00$ & $5.53 \pm 0.00$ \\
\hline 1 Ventral & $1 \max$ & $12.10 \pm 0.00$ & $17.60 \pm 0.00$ & $22.78 \pm 0.00$ & $11.07 \pm 0.00$ \\
\hline 1 Ventral & $2 \min$ & $3.88 \pm 0.55$ & $6.39 \pm 0.75$ & $12.73 \pm 1.69$ & $4.86 \pm 0.83$ \\
\hline 1 Ventral & $2 \max$ & $10.66 \pm 0.50$ & $15.63 \pm 0.69$ & $21.84 \pm 0.35$ & $10.40 \pm 0.25$ \\
\hline 1 Ventral & $3 \mathrm{~min}$ & $9.75 \pm 0.19$ & $14.39 \pm 0.25$ & $21.17 \pm 0.15$ & $9.93 \pm 0.10$ \\
\hline 1 Ventral & $3 \max$ & $7.92 \pm 0.07$ & $12.13 \pm 0.42$ & $19.72 \pm 0.30$ & $8.95 \pm 0.20$ \\
\hline 1 Ventral & $4 \mathrm{~min}$ & $6.46 \pm 0.18$ & $9.90 \pm 0.24$ & $20.16 \pm 4.00$ & $9.32 \pm 2.76$ \\
\hline 1 Ventral & $4 \max$ & $15.50 \pm 2.83$ & $22.23 \pm 3.86$ & $22.38 \pm 3.78$ & $10.84 \pm 2.62$ \\
\hline 2 Ventral & $1 \mathrm{~min}$ & $3.36 \pm 0.02$ & $5.67 \pm 0.03$ & $11.11 \pm 0.08$ & $4.07 \pm 0.03$ \\
\hline 2 Ventral & $1 \max$ & $10.40 \pm 2.25$ & $15.27 \pm 3.06$ & $21.51 \pm 1.68$ & $10.18 \pm 1.17$ \\
\hline 2 Ventral & $2 \mathrm{~min}$ & $4.35 \pm 0.53$ & $6.62 \pm 0.08$ & $13.36 \pm 0.16$ & $5.15 \pm 0.08$ \\
\hline 2 Ventral & $2 \max$ & $10.50 \pm 0.77$ & $15.42 \pm 1.04$ & $21.72 \pm 0.54$ & $10.31 \pm 0.38$ \\
\hline 3 Ventral & $1 \mathrm{~min}$ & $3.67 \pm 0.13$ & $6.10 \pm 0.17$ & $12.21 \pm 0.41$ & $4.58 \pm 0.20$ \\
\hline 3 Ventral & $2 \max$ & $7.42 \pm 0.47$ & $11.21 \pm 0.64$ & $19.00 \pm 0.51$ & $8.48 \pm 0.33$ \\
\hline
\end{tabular}

Table 4. $\mathrm{Mg} / \mathrm{Ca}$ ratios $(\mathrm{mmol} / \mathrm{mol})$ and temperatures $\left({ }^{\circ} \mathrm{C}\right)$ from the dorsal and ventral valves of Laqueus rubellus at locations of major spiral maxima and minima. $\mathrm{T}^{1}$ are temperatures resulting from the $\mathrm{Mg} / \mathrm{Ca}$ paleothermometry equation by Pérez-Huerta et al. (2008) based on modern brachiopods, $\mathrm{T}^{2}$ are temperatures resulting from the equation by Butler et al. (2015) based on the modern brachiopod Terebratulina retusa, and $\mathrm{T}^{3}$ are temperatures resulting from the equation by Butler et al. (2015) based on the modern brachiopod Liothyrella neozelanica. 


\begin{tabular}{|c|c|c|c|c|c|}
\hline Specimen & Deviation & $\mathrm{Mg} / \mathrm{Ca}(\mathrm{mmol} / \mathrm{mol})$ & $T^{1}$ & $\mathbf{T}^{2}$ & $\mathbf{T}^{3}$ \\
\hline 1 Dorsal & $1 \mathrm{~min}$ & $6.74 \pm 0.09$ & $10.29 \pm 0.12$ & $18.22 \pm 0.11$ & $7.97 \pm 0.07$ \\
\hline 1 Dorsal & $1 \max$ & $13.05 \pm 4.32$ & $18.89 \pm 5.89$ & $23.02 \pm 2.43$ & $11.26 \pm 1.73$ \\
\hline 1 Dorsal & $2 \min$ & $5.21 \pm 0.24$ & $8.19 \pm 0.33$ & $15.91 \pm 0.44$ & $6.56 \pm 0.26$ \\
\hline 1 Dorsal & $2 \max$ & $7.41 \pm 0.41$ & $11.20 \pm 0.55$ & $19.00 \pm 0.45$ & $8.47 \pm 0.29$ \\
\hline 1 Dorsal & $3 \mathrm{~min}$ & $5.58 \pm 0.03$ & $8.70 \pm 0.04$ & $16.56 \pm 0.05$ & $6.94 \pm 0.03$ \\
\hline 1 Dorsal & $3 \max$ & $13.47 \pm 0.88$ & $19.76 \pm 1.71$ & $23.66 \pm 0.66$ & $11.69 \pm 0.48$ \\
\hline 2 Dorsal & $1 \max$ & $11.40 \pm 0.85$ & $16.64 \pm 1.16$ & $22.80 \pm 0.90$ & $11.08 \pm 0.64$ \\
\hline 2 Dorsal & $1 \mathrm{~min}$ & $14.03 \pm 0.42$ & $20.22 \pm 0.57$ & $23.85 \pm 0.22$ & $11.83 \pm 0.16$ \\
\hline 2 Dorsal & $2 \max$ & $11.45 \pm 1.75$ & $16.71 \pm 2.39$ & $22.31 \pm 1.16$ & $10.73 \pm 0.82$ \\
\hline 2 Dorsal & $2 \mathrm{~min}$ & $7.93 \pm 0.64$ & $11.91 \pm 0.87$ & $19.53 \pm 0.63$ & $8.83 \pm 0.42$ \\
\hline 3 Dorsal & $1 \max$ & $6.06 \pm 0.00$ & $9.35 \pm 0.00$ & $17.29 \pm 0.00$ & $7.39 \pm 0.00$ \\
\hline 3 Dorsal & $1 \mathrm{~min}$ & $7.01 \pm 0.00$ & $10.66 \pm 0.00$ & $18.55 \pm 0.00$ & $8.18 \pm 0.00$ \\
\hline 3 Dorsal & $2 \max$ & $10.96 \pm 0.21$ & $16.04 \pm 0.29$ & $22.05 \pm 0.14$ & $10.55 \pm 0.10$ \\
\hline 3 Dorsal & $2 \min$ & $10.76 \pm 0.21$ & $15.76 \pm 0.29$ & $21.91 \pm 0.15$ & $10.45 \pm 0.10$ \\
\hline 3 Dorsal & $3 \max$ & $10.42 \pm 0.13$ & $15.31 \pm 0.18$ & $21.68 \pm 0.09$ & $10.28 \pm 0.07$ \\
\hline 3 Dorsal & $3 \min$ & $15.98 \pm 0.96$ & $22.89 \pm 1.31$ & $24.77 \pm 0.42$ & $12.50 \pm 0.31$ \\
\hline 3 Dorsal & $4 \max$ & $8.59 \pm 0.05$ & $12.81 \pm 0.07$ & $20.19 \pm 0.05$ & $9.26 \pm 0.03$ \\
\hline 1 Ventral & $1 \max$ & $8.91 \pm 1.06$ & $13.24 \pm 1.44$ & $20.44 \pm 0.93$ & $9.44 \pm 0.63$ \\
\hline 1 Ventral & $2 \mathrm{~min}$ & $11.06 \pm 2.34$ & $16.18 \pm 3.19$ & $22.80 \pm 1.07$ & $11.08 \pm 0.76$ \\
\hline 1 Ventral & $2 \max$ & $9.61 \pm 0.66$ & $14.20 \pm 0.90$ & $21.05 \pm 0.52$ & $9.85 \pm 0.36$ \\
\hline 1 Ventral & $3 \mathrm{~min}$ & $10.10 \pm 2.11$ & $14.87 \pm 2.88$ & $21.30 \pm 1.62$ & $10.04 \pm 1.12$ \\
\hline 2 Ventral & $1 \max$ & $11.30 \pm 0.66$ & $16.51 \pm 0.91$ & $22.27 \pm 0.44$ & $10.70 \pm 0.31$ \\
\hline 2 Ventral & $1 \mathrm{~min}$ & $8.75 \pm 0.58$ & $13.03 \pm 0.80$ & $20.33 \pm 0.52$ & $9.36 \pm 0.35$ \\
\hline 2 Ventral & $2 \max$ & $8.41 \pm 0.92$ & $12.56 \pm 1.25$ & $20.47 \pm 0.36$ & $9.45 \pm 0.24$ \\
\hline 2 Ventral & $2 \mathrm{~min}$ & $8.47 \pm 8.47$ & $12.65 \pm 0.05$ & $20.08 \pm 0.03$ & $9.19 \pm 0.02$ \\
\hline 3 Ventral & $1 \max$ & $11.77 \pm 0.00$ & $17.15 \pm 0.00$ & $22.58 \pm 0.00$ & $10.92 \pm 0.00$ \\
\hline 3 Ventral & $1 \mathrm{~min}$ & $7.53 \pm 0.00$ & $11.36 \pm 0.00$ & $19.14 \pm 0.00$ & $8.56 \pm 0.00$ \\
\hline 3 Ventral & $2 \max$ & $9.10 \pm 0.18$ & $13.51 \pm 0.61$ & $20.64 \pm 0.38$ & $9.57 \pm 0.26$ \\
\hline 3 Ventral & $2 \mathrm{~min}$ & $7.86 \pm 0.25$ & $11.81 \pm 0.34$ & $19.48 \pm 0.26$ & $8.79 \pm 0.17$ \\
\hline 3 Ventral & $3 \max$ & $9.87 \pm 0.39$ & $14.56 \pm 0.54$ & $20.71 \pm 0.98$ & $9.62 \pm 0.67$ \\
\hline 3 Ventral & $3 \mathrm{~min}$ & $7.40 \pm 0.43$ & $11.18 \pm 0.59$ & $18.98 \pm 0.48$ & $8.46 \pm 0.31$ \\
\hline 3 Ventral & $4 \max$ & $12.54 \pm 1.22$ & $18.19 \pm 1.66$ & $23.58 \pm 1.09$ & $11.64 \pm 0.79$ \\
\hline 3 Ventral & $4 \mathrm{~min}$ & $7.43 \pm 0.17$ & $11.52 \pm 0.37$ & $19.63 \pm 0.68$ & $8.89 \pm 0.46$ \\
\hline 3 Ventral & $5 \max$ & $13.94 \pm 0.50$ & $20.10 \pm 0.68$ & $23.80 \pm 0.26$ & $11.80 \pm 0.18$ \\
\hline
\end{tabular}

Table 5. $\mathrm{Mg} / \mathrm{Ca}$ ratios $(\mathrm{mmol} / \mathrm{mol})$ and temperatures $\left({ }^{\circ} \mathrm{C}\right)$ from the dorsal and ventral valves of Terebratula terebratula at locations of major spiral maxima and minima. $\mathrm{T}^{1}$ are temperatures resulting from the $\mathrm{Mg} / \mathrm{Ca}$ paleothermometry equation by Pérez-Huerta et al. (2008) based on modern brachiopods, $\mathrm{T}^{2}$ are temperatures resulting from the equation by Butler et al. (2015) based on the modern brachiopod Terebratulina retusa, and $\mathrm{T}^{3}$ are 
temperatures resulting from the equation by Butler et al. (2015) based on the modern brachiopod Liothyrella neozelanica. 